\title{
IMPORTS AND ROMAN IMITATIONS FROM THE MAIN DAVA TYPE SETTLEMENTS ON SIRET RIVER: BARBOŞI, POIANA, BRAD, RĂCĂTĂU
}

\author{
Sorin Cleşiu
}

\section{Importuri şi imitaţii de factură romană în principalele aşezări de tip dava de pe Siret: Barboşi, Poiana, Brad, Răcătău}

Articolul prezentat în acest volum reprezintă un studiu asupra principalelor dave de pe Siret, încercându-se o trecere în revistă a importurilor de factură romană şi a imitațiilor autohtone. În acest sens au fost luate în calcul piesele de port şi podoabă, fibule şi paftale, amfore prezentând inscripții sau ştampile, opaiţele, terra sigillata, sticla, monedele romane (denari republicani şi imperiali) descoperite în complexe închise (tezaure), de asemenea, imitaţiile după piesele romane realizate în atelierele locale. Pe baza materialului publicat în reviste de specialitate sau monografii şi analizat în acest studiu, am urmărit să realizez o trecere în revistă a materialului arheologic pentru fiecare din aşezările tratate, scopul fiind o încercare de determinare a secvențelor cronologice pentru fiecare aşezare. Au fost realizate hărţi şi tabele sugestive. Astfel, aşezarea de la Barboşi îşi începe existența probabilă în sec. III-II a. Chr. este foarte probabil ca sfârşitul acestei aşezări să fie legat de acțiunea guvernatorului Moesiei Tib. Plautius Silvanus Aelianus la nordul Dunăre. În cadrul aşezării de la Poiana se constată depunerile cele mai vechi îmcă din sec. V-IV a. Chr. aşezarea fiind părăsită definitiv la jumătatea sec. II p. Chr. - înc. sec. III p. Chr. Aşezările de la Brad şi Răcătău îşi încep existența în cu sec. IV a. Chr., sfârşitul acestora fiind probabil legat de războaiele daco-romane.

Key words: oppida, fortified settlements, imitations, imports, chronology.

\section{Archaeological research. Synthesis remarks}

From historiographic perspective the fortified settlements $\left(\right.$ poleis $\left.^{1}\right)$ from Siret Valley raised numerous and various substantive issues that were unsatisfactorily resolved, while studies reaching general conclusions on their development are only intended. We are addressing immediate practices underlined by Greek and Roman influences and proven by the outcome of the local production (imitations) or massive imports and the settlements abandonment (fig. 1), given that the Getae no longer appear as promoters of military or political initiatives. The organization of the Pontic coast and Aelius Catus (12 AD) or Tib. Plautius Silvanus Aelianus (57-67 AD) actions related to massive colonisation ended any warlike character of their society. Based on this observation, we shall argue that the settlements ending (termination or abandonment) as logical consequence of the Trajan`s wars may still be re-debated.

These fortifications exhibit all necessary features so to be framed within the oppida category. The term oppidum ${ }^{2}$ (oppida) derives from the Latin term ob-pedum meaning "closed place", fortification, other than typical, which might be identified with a proto-city, a strong economic, religious and military centre. This settlement type is found at Bibracte (Mont

\footnotetext{
${ }^{1}$ Ptolemy, Geogr. III 8, 4 and III 10, 8.

${ }^{2}$ Collis 2003, 149-158.
} 
Beauvray), Salon-de-Provence, Oppidum d'Ensérune, Manching, Glauberg, Alcimoennis, Stradonice, Obidos, Traprain Law, Maiden Castle, Verlamion. The settlements at Barboşi, Poiana (Piroboridava), Răcătău (Tamasidava), Brad (Zargidava) ${ }^{3}$ have dominant position (terraces and hilltops under the toponym "Cetățuia"), being located on heights so to be as inaccessible as possible. Thus, due to their specific location, archaeological investigation methods are also special, involving the draft of thorough stratigraphic differentiation, particular "collection" and examination of the archaeological material.

Within some of the settlements, archaeological research was hampered by modern derangement, which destroyed the archaeological level, like for instance at Barboşi ${ }^{4}$, where 1916 and 1918 military trenches as well as modern constructions seriously affected the investigation.

At Barboşi and Poiana, the first archaeological trial tranches were carried out between 1913-1914 by V. Pârvan, while original archaeological research was performed by Gh. Ştefan (Barboşi) and R. Vulpe (Poiana). Archaeological circumstances from Barboşi are most difficult, as the stratigraphic sections made by N. Gostar and S. Sanie failed to provide clear stratigraphic distinction ${ }^{5}$. The only settlements where complete archaeological research was achieved are those from Brad and Poiana, which benefit of monographs on methods, archaeological investigation and its results.

Stratigraphic issues are found in all investigated settlements: stratigraphy is confusing, and in certain cases inaccurate, the only settlement where it was reviewed is that from Poiana, the complicated division of the archaeological levels being simplified after new excavations being resumed by S. Teodor ${ }^{6}$. Additionally, the results of the new investigations were object of several articles regarding the material identified the following excavations (dress items and jewelry, coins, glass).

In 1970, Guy Rachet ${ }^{7}$ draw attention to the presentation of stratigraphic sections within publications, stating that "certain profiles appear as a confusing multitude of dark hatches between which one may hardly distinguish various levels...". The system mentioned by the author is familiar to us, as stratigraphic incoherence and obscurity are still a problem in some of the studied cases ${ }^{8}$. For this reason, we cannot speak about precedence, subsequence or concurrence, a conditio sine qua non for obtaining relative chronology.

The Bronze Age is very well represented by Monteoru Culture within the majority of settlements and we may add Monteoru fortifications at Brad and Răcătău and an important discovery from Răcătău, a hoard comprising 48 golden pieces deposited in a vessel type specific to this culture. Regarding the more or less overtake of Monteoru fortifications also in the classical Geto-Dacian period, it may be inferred that the Getae took over part of the fortification structures (rampart, ditch), however re-built and reinforced according to the new requirements of the time.

As mentioned above, the dominant position of the settlements examined herein provides them with good defence. The monographs focusing on their case, occasionally exaggerate the description of the fortification system, the term of "impregnable/inexpugnable" appearing as explanation for a fortification system that does not in fact comply with reality: the settlement from

\footnotetext{
${ }^{3}$ See, pl. 1 .

${ }^{4}$ Sanie 1987, 103-111.

${ }^{5}$ Gostar 1962, 508.

${ }^{6}$ Teodor 1992, 115-124.

${ }^{7}$ Rachet 1977, 95-96.

${ }^{8}$ See stratigraphic representation regarding Brad, Răcătău or Barboşi settlements.
} 
$\operatorname{Brad}^{9}$ would be accordingly, defended by an oversized ditch exceeding by much the acropolis surface and it definitely does not seem to be the result of human activity, but rather of nature ${ }^{10}$.

The settlement from Barboşi is probably most problematic due to defective excavation techniques both for the Roman period as well as the classical Geto-Dacian period. One wonders after such long period, if it could indeed be a proper "fortress" as called on various occasions,

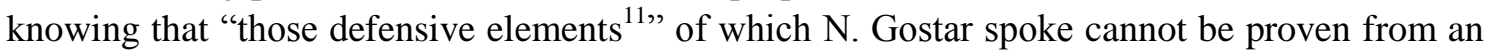
archaeological standpoint because they are not visible stratigraphically (unless re-opening the excavation, which is however impossible without careful map drawing, serious land survey and maximum use of modern archaeological means, otherwise we risking similar results).The reopening of numerous excavations from Barboşi is a rather difficult operation considering that modern destruction intensifies yearly, as the site is not protected.

At Poiana, in spite of intense inhabitancy, the single fortification element is represented by the rampart on the site's eastern side, excavations establishing it was made in the $1^{\text {st }} \mathrm{C}^{12}$ and the beginning of the $2^{\text {nd }} \mathrm{BC}$. It was dated based on a hoard of imperial Roman denarii (sic) discovered under curious circumstances and having no clear context, therefore it is hard to believe it was found in a closed complex.

The presence of cult constructions, the so-called "sanctuaries", is still an important point of contention. Thus, none of the graphical reconstructions of the grand cult constructions (proposed especially for Sarmizegetusa) was unanimously accepted by the scholars, consequently we are not sure either on their appearance or their function. In the case of the settlements under discussion, cult constructions were signalled at Barboşi, Brad, Răcătău, but unfortunately their existence may not be undeniable, as not any drum alignment certifies a sanctuary. Circumstances are uncertain at Răcătău where research has not been completed, while at Barboşi archaeological research indicated the discovery of a "modest" rectangularly-shaped ${ }^{13}$ sanctuary and at Brad, where a complexes ensemble possibly evolving from rectangular to circular sanctuaries was found.

The discovery of kilns for pottery firing and iron ore reduction (together with conicalshaped crucibles, vitrification traces, iron blooms) is important from an archaeological point of view, leading to the hypothesis that pottery and metallurgic workshops operated within the settlements, which must have had an important economic function.

Pottery firing kilns were identified at Poiana ${ }^{14}$ and five pottery firing and iron ore reduction kilns were also discovered at Răcătău ${ }^{15}$.

Except for Brad (Zargidava) ${ }^{16}$ and Poiana (Piroboridava) ${ }^{17}$, most archaeological results are gathered in site reports published within specialty publications, many summarising the archaeological research and everything it involved - stratigraphic analysis, pottery typologies, parallels and analogies with other fortified settlements of the type - thus impacting the interpretation of the investigation results.

The pottery, brooches and coins, the glass in certain cases are published as drawings or photos. The photos are, however, unclear and inaccurate representation means, the lack of the metric scale and of the differentiation between the technique (resulted from human action,

\footnotetext{
${ }^{9}$ Ursachi $1980,178-182$.

${ }^{10}$ Ursachi $1995,99-112$.

${ }^{11}$ Getae fortification elements might have been identified within I WW trenches, according to the hypothesis they largely followed the route of ancient fortifications.

12 Teodor 1992, 123

${ }^{13}$ Sanie 1987, 103-111.

${ }^{14}$ Vulpe 1950, 45.

${ }^{15}$ Căpitanu 1976, 49-71.

${ }^{16}$ Ursachi 1995.

${ }^{17}$ Vulpe, Teodor 2003.
} 
production or use) and the proper vessel, which represents the "evidence" recovered by the archaeologist, make them useless when drafting a catalogue or typologies. The items' drawing according to standards and clearly established conventions is essential for publication. All these objects (artifacts) are engaged within social contexts and relations that have to be determined for a better appreciation of the material culture, which is in fact, mainly, a pottery culture.

The manufacturing technique of these objects helps us understand their social significance. To this effect, S. Sanie's remark on the pottery division according to its purpose is important and I should add, according to the technique, meaning not only the proper processing process, either by hand or wheel, but also the function (use), technology, fabric (either coarse or fine), shape, decoration (latest innovations) and social significance of such pottery communities.

However, all these problems emerge when the material is incorrectly recorded in the field, hence the recommendation that material sheets (various types based on own precise methods) be used on contextual or stratigraphic unit bases, is not preposterous. The advantage of this type of recording is the automate identification of the discovered artifact with the stratigraphic unit or context. This method allows a first synthesis of the material under study and aids the typological analysis drafted by the archaeologist at the office, therefore, facilitates the completion of the typological sheet ${ }^{18}$. We do not intend to sound absurd when advancing this criticism, yet such issues are noticeable and damage persistently the archaeological finds presentation and we consider it appropriate - the bare enumeration of items without analogies, the analysis of the technique and decoration, remarks on dress and fashion, statistics, produce simple articles hindering the reader-researcher approach.

In conclusion, the material sheet, the item recording (labelling), the typological sheet, drawings, photos, comparative studies, chronologies - are fundamental for the accurate analysis leading to publication ${ }^{19}$.

Archaeology operates with two dating methods: the absolute and relative chronologies. The first is based on indices and concise measurements of various and auxiliary procedures (dendrochronology, ${ }^{14} \mathrm{C}-$ Carbon 14 etc.) for the absolute temporal establishment. The second method is based on precedence and subsequence relations between one event and the other, between a structure (artifact) or another, between a layer/level or another within the context of the archaeological excavation where the location of the objects corresponds to the temporal stratification.

Chronological studies of the Geto-Dacian period are limited, still, but it does not imply that the issue was not taken into consideration by Romanian scholars (even though, no notable results were reached), the article from the new "Tratat de istorie a românilor" ${ }^{20}$ raising yet numerous problems. Synthesizing, chronology was tackled by V. Pârvan ${ }^{21}$, K. Horedt' ${ }^{22}$ I. H. $\mathrm{Crişan}^{23}$, M. Babeş ${ }^{24}$, their studies ${ }^{25}$ remaining the most important and the single ones to approach the period chronology under all its aspects.

In 1975, first notable steps into this matter are taken by the article from "Dacia" journal, wherein M. Babeş starts from the premise that the Geto-Dacian davas had their own existence

\footnotetext{
${ }^{18}$ Jockey 1999, 259-274; Roskams, The stratigraphic record, 2001, 153-168.

${ }^{19}$ Harris 1979, 104, fig. 31.

${ }^{20}$ Tratat de istorie a românilor, v. I, 760-762.

${ }^{21}$ Pârvan 1927, 267, 464, 466.

${ }^{22}$ Horedt 1973, 127-167; Horedt 1976, 127-130.

${ }^{23}$ Crişan 1969, 9-232.

${ }^{24}$ Babeş 1975, 125-139.

${ }^{25}$ Babeș 2000, 323-338.
} 
delimited over five chronological horizons, the analysis being based on the study of the chronologically relevant archaeological material (Dacian pottery - directory fossils (the Dacian cup), imports, imitations, brooches, coins). The incomplete and provisional character of the information is invoked, alike today, as main obstacle in settling a solid chronology ${ }^{26}$. Additionally, the author does not pass this establishment as definitive, but presents it as a rather work hypothesis, a start point.

\section{Fortifications of Dava type from Barboşi, Brad, Poiana and Răcătău.}

Dinogetia Nova (?) (Barboşi, Galați county). Fortified settlement of Dava type

\section{ANCIENT NAME}

Several views were expressed regarding the ancient name of Barboşi locality. The first, considered that both Barboşi and Bisericuța-Garvăn were named Dinogetia Vetus? ? $^{27}$ Others, locate at Barboşi the mysterious Turris $^{28}$. It was also identified with Piroboridava $^{29}$ from the Hunt Papyrus (FHDR I, 470), while new maps associate it with Dinogetia Nova $^{30}$.

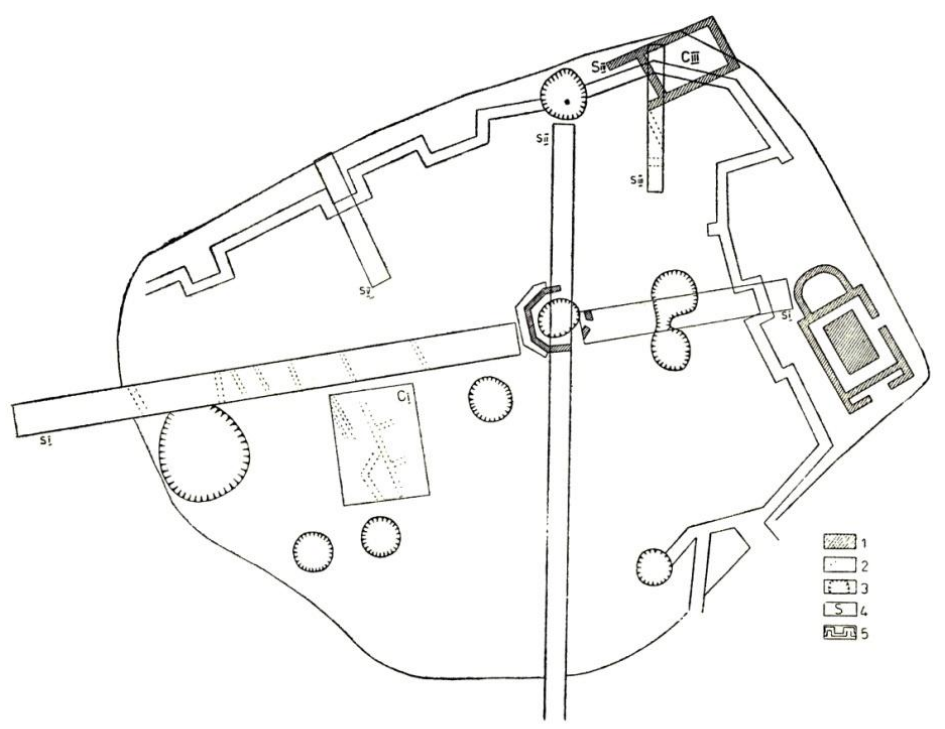

Fig. 1

\section{SITE DESCRIPTION}

The settlement located on the promontory Tirighina, known in the Middle Ages as Ghertina, is mentioned starting with the 17th c. by the Moldavian chronicler Miron Costin in Letopisețul Țării Moldovei and then by Dimitrie Cantemir in Hronicul vechimei a românomoldo-vlahilor.

Archaeological research is properly initiated in 1935-1936 (first sondages carried out by Vasile Pârvan in $1913^{31}$ ) coordinated by Gheorghe Ştefan ${ }^{32}$, continued by I. Vendelin ${ }^{33}$ in 1938, Nicolae Gostar (1959-1964) ${ }^{34}$ and Silviu Sanie $(1978-1983)^{35}$.

\footnotetext{
${ }^{26}$ Babeş 2000, 136.

${ }^{27}$ Vulpe 1957, 162, n. 22; Ştefan, 1958, 317-329.

${ }^{28}$ Comşa 1960, 731, n. 3.

${ }^{29}$ Gostar 1965, 146-147; Müller 1883, 468.

${ }^{30}$ Babeş, Bugă, Dobre, Rusenescu, Vulpe 1996, 103.

${ }^{31}$ Pârvan, 1913, 106-119.

${ }^{32}$ Ştefan, 1938, p. 341-349.

${ }^{33}$ Vendelin, 1939, 141.

${ }^{34}$ Gostar, 1962, 144-147.

${ }^{35}$ Sanie 1981; Sanie1983, 141-151.
} 
The fortification at Barboşi is simple, consisting of a ditch on the northern side, the most vulnerable, since the eastern and southern sides were more difficult to access.

The earth-and-timber palisade was approximately 4 to $5 \mathrm{~m}$ high; it was rebuilt both in the Geto-Dacian as well as the Roman periods, when the agger is remade for the purpose of the settlement's maximum use.

\section{CATALOGUE OF DISCOVERIES}

\section{IMITATION $^{36}$ AND IMPORTS}

\section{Amphoras}

1. Amphora with semiround rim, $11 \mathrm{~cm}$ wide, relatively short neck, with a groove on the neck joining line with the truncated cone shoulder. Bifid handles attached under the rim and in the middle of the shoulder. The cylindrical body of the first two lenghtens gradually and thins down ending in a small conical base. The period of maximum spread is between the $2^{\text {nd }}-1^{\text {st }} B C$ and extends with small changes until the beginning of the $1^{\text {st }} \mathrm{AD}^{37}$.

2. Amphora with semiround rim, tall cylindrical neck, projecting in the upper part. A groove marks the transit to the narrow, short shoulder. Bifid handles attached under the rim and by the shoulder base. Almost spindly body, cylindrical in the first part, gradually thins down into a probable conical base (lower part missing), dated in $1^{\text {st }} \mathrm{BC}-1^{\text {st }} \mathrm{AD}$.

Amphoras with inscriptions

1. Fragment of a large amphora neck, made of compact yellowish fabric, exhibits a "CCF" glyph inscription in the third part of the lower neck. Letter " $\mathrm{C}$ " is circular and has a dot in the middle. Among amphoras stamped with initials representing tria nomina, those displaying letters "CCF" are unknown, except for two exemplars coming from Italy and England. The inscription might have been an acronym for $C C$ (alpurni) $F($ laci?) or $C$ Caristianus Fronto, a senator under Domitian (C. CAR. FRONT) $)^{38}$.

2. The neck fragment of an amphora made of pigmented yellowish fabric, covered with light yellowish angoba, displays an inscription in cursive Greek and a monogram painted in black paint.

The first row forms the preposition 'Epi. The line of letter D, first letter of the following word, is close to a flatway $\mathrm{A}$, frequent in cursive texts both in the $2^{\text {nd }} \mathrm{BC}$ as well as the $1^{\text {st }} \mathrm{AD}$, is followed by the letter group tovv, the anthroponym $\triangle$ IONISIOS in Genitive. Letters $\alpha \sigma \tau v$ may be distinguished (written obliquely) over this first row and by the end, letters X $\omega \rho$ can be barely read.

The monogram from the second row may have various readings, thus it may represent the crafter's abbreviated name, a function within the community, the recipient content etc. It is hard to read and several variants were produced, NEP, NEPI, $\left(\nu \epsilon^{\prime} \rho(\tau) \epsilon(\rho O S)\right)$, inferior, which is from below or APVE, АРУГЕ, ГРУЕ ${ }^{39}$ ). The text of the inscriptions as it follows: 'E

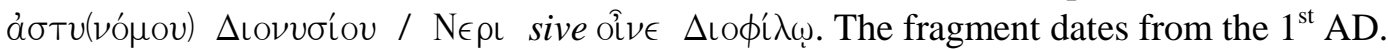

3. Amphora fragment made of reddish-yellow fabric, covered in yellowish angoba, preserving five letters painted in black, arranged on two rows AY, POY (possible acronyms for $\Lambda$ v́⿴囗os, Poú $\phi$ os), dated $1^{\text {st }} \mathrm{BC}-1^{\text {st }} \mathrm{AD}^{40}$.

\footnotetext{
${ }^{36}$ Sanie, Sanie 1992, 71-96, the author does not tackle the imitations issue, although at Barboşi there are imitations of cups with relief decoration, see Franga 1967, 7-35 and Glodariu, 1974, fragmentary bowl (?) 2nd - first half of the 1 st BC, 210.

${ }^{37}$ Sanie, Sanie 1992, no. 3 (anepigraphic amphoras) 72.

${ }^{38}$ Sanie, Sanie 1992, 80, pl. VII/5.

${ }^{39}$ Sanie, Sanie 1992, 82, pl. VII/1.

${ }^{40}$ Sanie, Sanie 1992, 82, pl.VII/3.
} 


\section{Luxury ware}

Three fragments of three different recipients were discovered (probably skyphoi) belonging to the category of lead-glazed pottery (Bleireliefkeramik), manufacture technique known in Asia Inferior, mid $1^{\text {st }} \mathrm{BC}$; the handles and rim shapes together with the decoration elements determine their dating in the $1^{\text {st }} \mathrm{BC}-1^{\text {st }} \mathrm{AD}$; in addition, the vessel working by applying barbotine on raw clay and the repeated painting make the fragments from Barboşi resemble the products of Smyrna workshops ${ }^{41}$.

Terra sigillata (plain or barbotinated)

1. Truncated cone-shaped bowl worked of compact, well fired yellowish-red fabric, both surfaces covered in light-red glaze. Carenated shoulder and vertical rim with two grooves, dated in the $1^{\text {st }} \mathrm{BC}$ but also in the subsequent period ${ }^{42}$.

2. Truncated cone-shaped bowl worked of compact, well fired yellowish-red fabric, both surfaces covered in light-red glaze, rim slightly bevelled inwards, same dating ${ }^{43}$.

3. Dish fragment, made of compact, well fired yellowish-red fabric, covered with lightred angoba with specific shine. The rim is decorated in relief with edgy leaves, obtained by barbotine (the petioles are alternatively inwards and outwards returned); ring base. This dish type (Dragendorf 36 ) is recorded from mid $1^{\text {st }} \mathrm{AD}$, very well distributed under the Flavians and in the $2^{\text {nd }} \mathrm{AD}$, included in the south-Gaul ware ${ }^{44}$.

4. Two fragments probably belonging to a plate, worked of fine yellowish-red fabric, covered in shiny reddish-brown glaze. The upper, semiround part of the rim is decorated with vertical incisions. The middle is concave and separated from the lower convex part by a groove. Two circular incisions may be observed on the rim line, in the upper part of the plate body. Plates of this type are frequent among Arretian products of the first half of the $1^{\text {st }} \mathrm{AD}^{45}$.

Of the four identified fragments, only one probably belonged to the same plate; its base preserves the marking $\mathrm{B} v \delta \mathrm{ol} / \mathrm{p} / \mathrm{F}$ painted in red.

5. Kantharos made of compact and well fired grey fabric, covered with a slip which after firing turned reddish-yellow, has a groove under the rim; the cylindrical body is slightly projecting in the handles fixing area, thinned middle, marked by a line in relief. The lower part is truncated cone- shaped and ends with a supporting ring. The vessel lacks both handles ${ }^{46}$, dates probably in the $1^{\text {st }} \mathrm{AD}^{47}$.

6. Kantharos made of compact, reddish-yellow fabric, well, however carelessly and unevenly fired, with reddish angoba. The vessel has profiled rim and arched handles ${ }^{48}$.

7. Fragments belonging to a skyphos made of fine, compact, very well fired yellowish fabric, covered on both surfaces with dark orange glaze. The rounded rim on the exterior is bevelled inwards. The recipient body preserves almost a third, both parts are of truncated cone shape. A horizontal rod, in the shape of a chapiter type known with Boscoreale cups, overlays a very probable ring-shaped handle, based on its preserved ends ${ }^{49}$.

\footnotetext{
${ }^{41}$ Sanie, Sanie 1992, 84, "two-coloured ware, ornamented in the barbotine technique were recorded only in inhabitancy levels subsequent to $80 \mathrm{BC}$ ".

${ }^{42}$ Sanie, Sanie 1992, 87, pl. X/3; Sanie 1974, 410, pl. 1.

${ }^{43}$ Sanie, Sanie 1992, 84 pl. X/1; Sanie 1974, 410, pl. 2/4, 7, 12, three fragments of small truncated cone-shaped bowls, close as technique with the above exemplars, probably same dating.

${ }^{44}$ Sanie, Sanie 1992, 83, pl. VIII, 1a and 1b; Sanie, 1974, 410.

${ }^{45}$ Sanie, Sanie 1992, 85.

${ }^{46}$ Sanie, Sanie 1992, 86, pl. IX/1; Sanie 1974, 413, pl. 1/5.

${ }^{47}$ Glodariu 1974, 210 sqq. (Catalogue of the import ware).

${ }^{48}$ Sanie, Sanie 1992, 85, pl. IX/3; Sanie 1974, 413, pl. 3/2.

${ }^{49}$ Sanie, Sanie 1992, 86, pl. IX/5 and pl. XII.
} 
8. Fragment of a brown, fine, compact and well fired fabric small cup, covered on the entire surface with brown angoba. A groove may be noticed between the vertical, slightly everted rim and the horizontal rod overlaid on the semicircular handle. Two parallel horizontal grooves may be observed towards the base of the cylindrical body, before the truncated cone portion, dated in the $1^{\text {st }} \mathrm{AD}^{50}$.

\section{Lamps}

1. Lamp made of light-red fabric, covered with brown angoba. The circular body is flattened; small and round nozzle, concave discus with filling-hole in the central part. The discus is separated from the broad rim decorated with double ovals by a circular groove, while the nozzle is separated from the discus by a stalk. The item has flat base and no handle. Known to originate from central Italy and Campania officinae. It probably belongs to type Q 1218 in Loeschcke classification or type XVIII in C. Iconomu classification. Recorded in necropolis from Tomis and graves from the $1^{\text {st }}, 2^{\text {nd }}$ and $3^{\text {rd }} \mathrm{AD}$ (the author dates it in the $\left.1^{\text {st }} \mathrm{AD}\right)^{51}$.

2. Fragment representing part of a lamp discus and shoulder, made of fine, yellowish fabric covered in brown angoba. Eros (Cupid) is displayed on the discus, separated from the shoulder by a circle segment in relief and other two incised. The winged character leans on the right foot, the left one is slightly distanced and heightened; the joining hands on the right foot posture are probably prepairing to throw something. Cupid appears frequently beside other gods on lamps, his posture is similar to the association with Diana, the item having analogies with lamps from Gaul (50-80 $\mathrm{AD}$ ) or Campania, from the last third of the $2^{\text {nd }} \mathrm{AD}^{52}$.

3. Fragment of a lamp upper part, made of yellowish fabric, covered with yellowish angoba. The row of double ovals from onto the shoulder is discontinued on the nozzle line, the nozzle notch being flanked by two volutes. The discus is decorated with a rosette, most probably with 25 petals, on its entire surface, 11 being visible on the preserved fragment; in addition, it is separated from the shoulder by two circular grooves and other two towards the filling-hole. Hypothetical framing and dating (probably type $\mathrm{X}$ according to C. Iconomu or Loeschke type, dated probably in the first half of the $1^{\text {st }} \mathrm{AD}$, being very well spread in the period from Tiberius to Trajan $)^{53}$.

4. Upper part of a lamp made of yellowish-red fabric, covered in red glaze. It has a lamellar-shaped handle with a middle cut groove and filling-hole in the centre of the concave discus. Separated from the discus by a circular groove, the broad shoulder is ornamented with vine leaves and grapes. The decoration is discontinued on the nozzle line where parts of two volutes that covered only the central part of the space between the discus and nozzle may be observed. The two are flanked, towards the rim, by two deepened circular-shaped small ornaments (the nozzle shape is uncertain), dated in the $1^{\text {st }} \mathrm{AD}^{54}$.

5. Fragmentary lamp with round belly, made of yellowish-red fabric, covered unevenly with brown angoba on the shoulder, the annular ansa with middle groove and on part of the basin surface. The concave discus is delimited from the non-ornamented shoulder by three incised circles. According to the preserved shape, the nozzle seems to have been small, heartshaped. The type framing remains hypothetical, the author dates it in the $1^{\text {st }} \mathrm{AD}^{55}$.

6. Fragmentary lamp made of yellowish-red fabric covered with good quality light-red glaze. It has a concave discus separated from the shoulder, ornamented with semiovals, by a

\footnotetext{
${ }^{50}$ Sanie, Sanie 1992, 86, pl. IX/4.

${ }^{51}$ Sanie, Sanie 1992, 92, pl. XIII/1.

${ }^{52}$ Sanie, Sanie 1992, 92, pl. XIII/4.

${ }^{53}$ Sanie, Sanie 1992, 92, pl. XIII/6.

${ }_{55}^{54}$ Sanie, Sanie 1992, 89, pl. XII/5; Sanie 1974, 413, pl. 5/7.

${ }^{55}$ Sanie, Sanie 1992, 92, pl. XIII/2.
} 
circular groove, the wall of the truncated-cone basin is slightly rounded, flat resting surface. Some incisions may be observed on the discus. It is possible that the nozzle was small and round. The lamp is dated by the end of the $1^{\text {st }} \mathrm{BC}$ - beginning of the $1^{\text {st }} \mathrm{AD}^{56}$.

7. Fragmentary lamp made of fine yellowish fabric, with traces of red glaze. The massive lamellar handle, part of the shoulder and basin are preserved only. Same dating with the previous lamp ${ }^{57}$.

\section{Glass $^{58}$}

Fragments belonging to several glass recipients (comprising ware and beads, balsamarium (unguentaria), glass bowls) were discovered within the settlement at Barboşi, however no complete or restorable items could be found.

Thus, there were identified fragments belonging to certain balsamarii (unguentaria; the neck of two items), dated in the $1^{\text {st }} \mathrm{AD}$, respectively the second half of the $1^{\text {st }} \mathrm{c}-$ end of the $2^{\text {nd }} \mathrm{AD}$.

Additionally, there were uncovered fragments pertaining to glass recipients $\left(1^{\text {st }}-2^{\text {nd }} A D\right)$ and bowls, the so-called glass "ribbed" bowl and of Fadenschalchen type, dated in the $1^{\text {st }} \mathrm{AD}$.

A glass paste-made ring was also discovered, round in cross-section, with a wound stripe decoration consisting of yellow, blue and silvery lines ending in a loop on the flat part. Complete or fragmentary glass rings were also found in other Geto-Dacian settlements and, in addition, Roman glass rings are found during the entire ancient period, from La Tène until the $3^{\text {rd }} \mathrm{AD}^{59}$ together with several types of beads dated in the $2^{\text {nd }} \mathrm{BC}-2^{\text {nd }} \mathrm{AD}$.

\section{Dress items and jewelry}

\section{Brooches}

1. Glasinač bronze brooch fragment, semicircular, symmetrical bow, round in crosssection, gets thinner towards the returned ends, probably to the pin, respectively the triangular catchplate. Glasinač brooches were largely distributed and their evolution lasted over four centuries (VIII - VII; VI - V BC). We cannot ascertain that the brooch proves a previous level to the pre-existent, still unidentified in the field ${ }^{60}$ (the brooch comes from an inhabitancy level where the other materials do not go beyond the $2^{\text {nd }} \mathrm{BC}$ )

2. Iron brooch with bilaterial spring made of four coils, internal chord, slightly curved bow, rectangular in cross-section, flat. The poorly preserved brooch lacks most part of the bow and the catchplate. Similar brooches in shape and size are known from many Geto-Dacian settlements. Exemplars found in well dated complexes belong to a period between the $1^{\text {st }} \mathrm{BC}$ until mid $1^{\text {st }} \mathrm{AD}^{61}$.

3. Small bronze brooch, proorly preserved, slightly curved bow, triangular in crosssection, bilateral spring made of four coils, internal chord. The pin is detached from the spring, the catchplate is missing, dated in the $1^{\text {st }} \mathrm{AD}^{62}$.

4. Silver "spoon" brooch (La Tène D type), the bow head is widended in the shape of a spoon (it is not a Nauheim brooch, as the author argues ${ }^{63}$ ) and lamellar on the remaining length (including the foot), ornamented with incised lines or longitudinal notches, the catchplate is in the

\footnotetext{
${ }^{56}$ Sanie, Sanie 1992, 89, pl. XII/6.

${ }_{58}^{57}$ Sanie, Sanie 1992, 89, pl. XII/1; Sanie 1974, 413, pl. 5/2.

${ }^{58}$ Sanie, Sanie 1992, 93, pl. XIV/ 1-12.

${ }^{59}$ Sanie, Sanie 1992,88 , pl. XI/4.

${ }^{60}$ Sanie, Sanie 1991, 47, pl. I/11 a, b.

${ }^{61}$ Sanie, Sanie 1991, 47, pl. I/3.

${ }^{62}$ Sanie, Sanie 1991, 47, pl. I/2.

${ }^{63}$ Sanie, Sanie 1991, 47, pl. I/7.
} 
shape of a frame, either pierced or full. The maximum use period of these brooches is comprised between the last quarter/end of the $1^{\text {st }} \mathrm{BC}$ until mid/third quarter of the $1^{\text {st }} \mathrm{AD}^{64}$.

5. Roman type brooch with bilateral spring (Norico - Pannonian) with two knots on the bow, exterior chord supported by a hook, while the catchplate is pierced or frame - shaped, made of bronze. It is well preserved, only the pin and the edge of the catchplate requiring restoration. The brooch is dated during the entire $1^{\text {st }} \mathrm{AD}$, occasionally later ${ }^{65}$.

6. Brooch discovered by Gh. Ştefan in the fourth decade, bronze made, has a semicircle curved bow, decorated with a zig-zag incised line, short foot decorated with biconical knob. The brooch is part of hinged Roman brooch types, the author's suppositions regarding its resemblance with the Nauheim type ${ }^{66}$ being speculative. The item is probably an Aucissa brooch (? $)^{67}$. It is dated, in case identification was correct, by the end of the $1^{\text {st }} \mathrm{BC}-1^{\text {st }} \mathrm{AD}$ and even later.

7. Fragmentary brooch, according to the author's description "in the shape of a trumpet (?)" ${ }^{\prime 68}$, however based on the drawing, we suppose it is an Eastern strongly profiled brooch (the brooch has approximately 9 or 10 coils, with a spring protection plate and a knot on the bow $)^{69}$, dated by the end of the $1^{\text {st }} \mathrm{AD}$ until the beginning of the $2^{\text {nd }} \mathrm{AD}$.

\section{Coins}

Two coin hoards were uncovered within the Geto-Dacian settlement from Barboşi. One was found under not accurately determined circumstances, Gheorghe Săulescu indicating in "Descrierea istorico - geografică a cetăței Caput Bovis (Capul Boului sau Ghertina) $)^{70 "}$ that it could be dated between the $2^{\text {nd }}$ c. $-3^{\text {rd }} \mathrm{AD}$.

The second hoard was found in 1915 and published by G. Severeanu "Tesaurul din Ghertina. Contribuțiuni la începuturile numismaticei române în ținuturile dunărene şi ale Dobrogei de astăzi ${ }^{71}$ ".

The hoard comprised 517 denarii of which 493 were republican, 12 from emperor Octavianus Augustus, 11 copies and one coin from the Numidian king Juba I (G. Severeanu describes 340 coins).

The coins are dated from $217 \mathrm{BC}$ - years $2-4 \mathrm{AD}$, at Barboşi being also discovered Histrian coin issues $\left(2^{\text {nd }}-1^{\text {st }} \mathrm{BC}\right)$, Tomis coins $\left(1^{\text {st }} \mathrm{BC}-1^{\text {st }} \mathrm{AD}\right)$, a coin issue from Maroneea $\left(2^{\text {nd }} \mathrm{c}-1^{\text {st }} \mathrm{BC}\right)$. Insofar, except for a coin $\operatorname{die}^{72}$, flans and crucibles, no Geto-Dacian coins were found within the settlement or inside the fortified area.

West-Pontic issues are represented by a Histrian exemplar discovered in the agger and dated in the $2^{\text {nd }}-1^{\text {st }} \mathrm{BC}$ and by four Tomis items, of which one is a coin issued under Rhometalces I (11 BC - $12 \mathrm{AD})$. The three presented exemplars are not given an accurate chronological framing, however it is mentioned that one (the third item in the author's catalogue $^{73}$ ) was discovered in the first Dacian level.

\footnotetext{
${ }^{64}$ Rustoiu 1997, 48-50; list no. 14 for "spoon" type brooches, p. 108.

${ }^{65}$ Sanie, Sanie 1991, 47, pl. I/4; Rustoiu 1997, 57-58, based on the typology drafted by the author, the brooch belongs to type $24 \mathrm{c}$, List no. 21 for items of this type, p. 113.

${ }^{66}$ Sanie, Sanie 1991, 47, pl. I/5.

${ }^{67}$ Rustoiu 1997, 59-60.

${ }^{68}$ Sanie, Sanie 1991, 47, pl. I/1.

${ }^{69}$ Rustoiu 1997,53 , probably type 20 b, p. 112, according to the author's typology this brooch type does not appear in the catalogue drafted by S. Sanie.

${ }^{70}$ Săulescu, 1837.

${ }^{71}$ Severeanu, 1919, 45-140.

72 Sanie 1991, 53-54, the author presents and describes a coin die framed chronologically in the second phase of the Geto-Dacian mint, respectively $150-70$ BC.

${ }^{73}$ Sanie 1991, 54, isolated coins (pct.3).
} 
15 imperial coins were found, as follows: a coin issued at Pergamum (AUGVSTV[S]) and dated in $19 \mathrm{BC}$, three coins from emperor Claudius, 50 - $54 \mathrm{AD}$, a sestertius from emperor Nero (54-68 AD) (dating ?) and five coins from emperor Vespasian comprised between $69-71$ (the oldest) and $79-81 \mathrm{AD}$.

A Bosporan (?) issue was identified beside the above mentioned, however its identification is uncertain as it is poorly preserved.

\section{Zargidava (Brad, Negri commune, Bacău county)}

Fortified settlement of Dava type (oppidum), unenclosed settlement

\section{ANCIENT NAME}

Claudius Ptolemaeus (100-170 AD) - the third book of Geographia presents Dacia and Moesia $^{74}$. Based on his accounts, the fortified settlement from Brad was identified as ancient Zargidava.

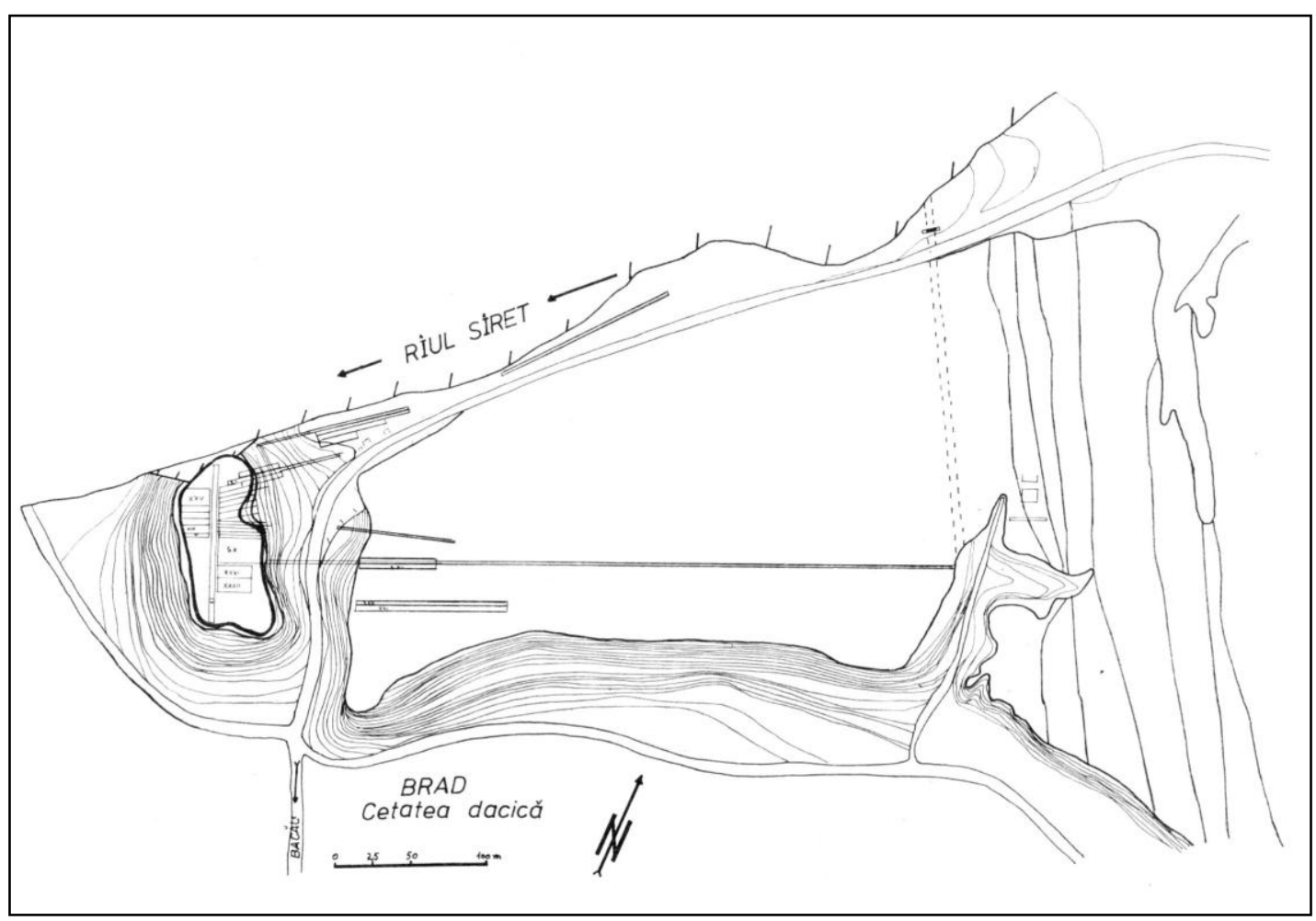

Fig. 2

\footnotetext{
${ }^{74}$ Ptolemy, Geogr, III, 10, 8.
} 


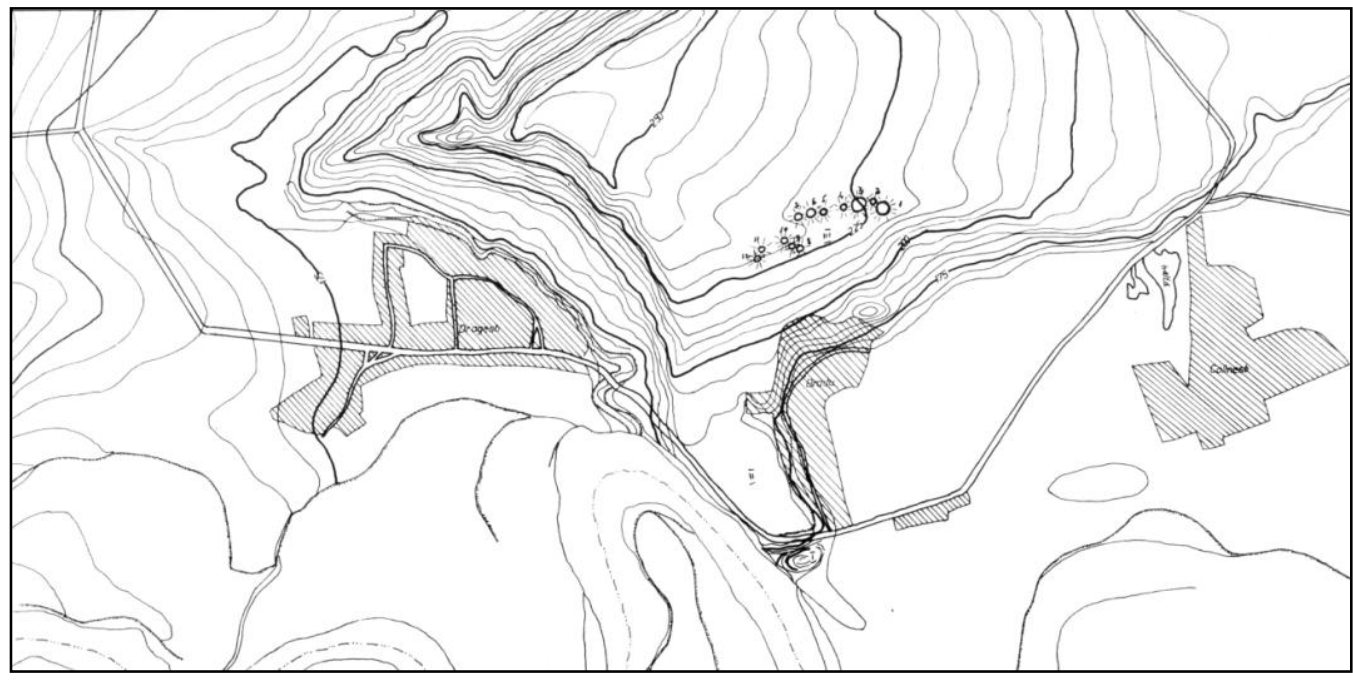

\section{SITE DESCRIPTION}

Fig. 3

The fortified settlement is S-W of Brad village, on the left terrace of Siret River, Negri commune, Bacău county and lays over a surface of approximately $7000 \mathrm{~m}^{2}$. First archaeological research was initiated by A. Vulpe in 1962, continued by Vasile Ursachi starting with 1963 until 1984.

The site stratigraphy consists of a succession of four inhabitancy levels; the Aeneolithic period represented by Cucuteni culture; the Monteoru culture for the Bronze Age; Hallstatt and La Tène $\left(4^{\text {th }} \mathrm{BC}-2^{\text {nd }} \mathrm{AD}\right)$

This "acropolis" was fortified beginning with the Bronze Age (Monteoru I c2-Ia) and comprised a ditch and rampart reinforced with cobbles. In the $1^{\text {st }} \mathrm{BC}$ a strong fortification was erected, including a trapezoid ditch and palisade, the defensive ditch escarp being reinforced with posts, logs and timber buttresses. The fortification loses its defensive function starting with the $1^{\text {st }} \mathrm{AD}$.

A "square" arranged from cobbles was identified in the centre of the "acropolis" and, at little distance from it, a sanctuary was found.

\section{CATALOGUE OF DISCOVERIES}

\section{IMITATION AND IMPORTS}

Pottery imitations are not considered in the author's catalogue as separate category, being mixed with hand and wheel-made pottery or the painted pottery.

Thus, the bowls (made by the hand working of the fabric) are considered imitations of the black glazed Greek pottery, chronologically framed in the $5^{\text {th }}-1^{\text {st }} \mathrm{BC}$.

The kantharos vessels, imitations of Greek and Roman ware; in the case of this vessel, the author identifies six typological variants without making chronological determinations. 540 items $^{75}$ were identified on the acropolis (in the last Dacian levels, $1^{\text {st }} \mathrm{BC}-1^{\text {st }} \mathrm{AD}$ ) and 80 exemplars within dwellings and pits.

The majority are made of grey fabric and only a few of red fabric (50 exemplars on the acropolis and 35 in the unenclosed settlement). In the latter, of 299 vessles, 11 were identified

\footnotetext{
${ }^{75}$ Ursachi 1995, 201, within the catalogue part "Other pottery items" a Kantharos is included without mentioning whether complete or only fragments were preserved, without date.
} 
in the first Dacian level $\left(3^{\text {rd }}-1^{\text {st }} \mathrm{BC}\right)$, the rest being discovered in the other two levels $\left(1^{\text {st }} \mathrm{BC}-\right.$ $\left.1^{\text {st }} \mathrm{AD}\right)$.

The bowls (wheel-made) are divided by the author in three variants. The first two are dated in the $3^{\text {rd }} \mathrm{BC}-2^{\text {nd }} \mathrm{AD}$; the last variant, represented by imitations of cups with relief decoration (Delian) is the most important, a single exemplar ${ }^{76}$ being discovered within the Brad settlement, framed chronologically in the $2^{\text {nd }}$ - beginning of the $1^{\text {st }} \mathrm{BC}$ (typologically they are framed in the second category of the semi-spherical cups, according to the framing made by $\mathrm{I}$. Franga in "Arheologia Moldovei" V/1967).

Kraters, three imitations of this ware type (emerged as early as the $5^{\text {th }} \mathrm{BC}$ in the south Thracian region) were identified on the acropolis and one in the unenclosed settlement corresponding to the $1^{\text {st }} \mathrm{BC}-1^{\text {st }} \mathrm{AD}$.

Imitations of the Greek vessel of Kernos type, two types were discovered at Brad (annular belly, tubular shape); fragments and protomes were preserved from the first type, the vessel being made so to be worn on the head. The second vessel type is provided with a stem for maintaining it in vertical position; the author relates it to the circular sanctuary, as the vessel was discovered in a pit from its close vicinity. This vessel type, copied by the Dacians, is dated in the $2^{\text {nd }} \mathrm{BC}-1^{\text {st }} \mathrm{AD}$. Only three, however painted vessels of this type were discovered, two in the acropolis and one in the unenclosed settlement decorated with horizontal stripes.

Painted Kantharos vessel imitations comprise two groups: the footed-vessel and vessels with ringed resting surface. In Brad settlement, 132 items were identified on the acropolis and 52 in the unenclosed settlement, dated in the $1^{\text {st }} \mathrm{BC}$.

The most spread recipient type discovered mostly fragmentary is the amphora; fragments exhibiting stamps were not identified.

Cos and Pseudo-Cos amphora types dated in the $1^{\text {st }} \mathrm{BC}-2^{\text {nd }} \mathrm{AD}^{77}$ were discovered (438 fragments on the acropolis and 121 in the unenclosed settlement); Rhodian amphoras (largest number of such amphoras fragments, 702 on the acropolis and 251 in the unenclosed settlement) dated probably in the $1^{\text {st }} \mathrm{BC}-1^{\text {st }} \mathrm{AD}$, Kios amphoras, $4^{\text {th }} \mathrm{c}$. $-3^{\text {rd }} \mathrm{BC}$, Thasian amphoras, determined chronologically based on the study of their resting surfaces and handles in the $4^{\text {th }} \mathrm{c}$. $-2^{\text {nd }} \mathrm{BC}$.

The vast majority of the import objects are fragmentary, and we classified the items presented by the author upon decoration and fabric, if applying. Thus, they could be plain, with red angoba or terra sigillata, with red, grey or kaolinite fabric.

Among Kantharos vessels ${ }^{78}, 10$ are complete or restorable items, five are fragmentary, the rest of 113 presented items being fragments. Among them, 22 are terra sigillata, with red angoba, glazed (white, brown or green), with barbotine or painted in white, 3 are made of kaolinite fabric, the rest of 113 having red angoba and simple decoration of incised lines, while only three pottery fragments are painted.

There are only five complete Kantharos vessels, the rest being restorable (lacking their handles); in addition, we notice only a single terra sigillata; all vessels are made of red fabric and only two exemplars have angoba, one being decorated with barbotine. A special case is the single exemplar discovered in a cremation grave (in the $\mathrm{N}-\mathrm{E}$ limit of the unenclosed settlement).

\footnotetext{
${ }^{76}$ Ursachi 1995, 538, pl. 282/7.

77 The chronological framing is made according to Sanie 1992, 71-81, for instance his framing of the amphoras discovered at Barboşi is not the $4^{\text {th }} \mathrm{BC}$, as Ursachi shows.

${ }^{78}$ Ursachi 1995, 211-215.
} 
The Kantharos vessels are discovered in the vast majority in the last two Dacian stratigraphic levels $1^{\text {st }} \mathrm{BC}-1^{\text {st }} \mathrm{AD}$, the imports starting with the $2^{\text {nd }} \mathrm{BC}$.

The cup is discovered almost exclusively fragmentary and only one exemplar is complete. Of 89 fragments, 27 are terra sigilata, 6 are painted, the rest are exhibiting barbotine, glaze or are plain, decorated with leaves or other motifs.

The complete exemplar is yellowish-red, has cylindrical body, everted rim, annular base. It is provided with a stripe handle that starts from under the rim to the shoulder. It was discovered in a pit dating from the $1^{\text {st }} \mathrm{BC}$. The cup is imported starting with the $2^{\text {nd }} \mathrm{BC}$, the fragments discovered at Brad being dated in the $1^{\text {st }} \mathrm{BC}-2^{\text {nd }} A D$.

There are only 4 complete plates, the rest of 41 items being fragments, in addition only 4 fragments are terra sigillata, dated in the $1^{\text {st }} \mathrm{BC}-1^{\text {st }} \mathrm{AD}$.

Only fragments of bowls and dishes were found as well, with five complete exemplars out of 23 bowls $\left(1^{\text {st }}-2^{\text {nd }} A D\right)$ and 8 complete exemplars out of the 24 dishes $\left(1^{\text {st }}-2^{\text {nd }} A D\right)$.

Censers are fewer (of 16 fragments only one is complete and was discovered in a cremation grave located in the unenclosed settlement, dated in the $1^{\text {st }} \mathrm{BC}$ ), two fragments of cups with decoration in relief $\left(1^{\text {st }} \mathrm{BC}-1^{\text {st }} \mathrm{AD}\right)$, the vessel with inverted rim $\left(1^{\text {st }}-2^{\text {nd }} A D\right)$.

\section{Glass}

We noticed that the author's presentation lacked imported glass ware however, not entirely, 32 fragments ${ }^{79}$ being discovered, which we cannot identify from description (thus, there are 26 vessel fragments, 2 beaker fragments, handles and bases, no complete or restorable vessel). All 32 fragments were discovered in the last stratigraphic Dacian level ( $\left.{ }^{\text {st }} A D\right)$. Compared to other settlements from Moldova (Poiana, Barboşi, for instance), the glass ware finds from Brad are very much reduced compared to other imports, which are many.

\section{Dress items and jewelry \\ Brooches}

The presented catalogue ${ }^{80}$ comprises brooches, bracelets, earrings, buckles, rings, appliqués, pendants and other dress items and jewelry; our criticism is related to the way they were presented (for instance the plates, which in some cases do not help identify the described item, in addition, other items on the plates are not described ${ }^{81}$ ) and the recognition accuracy of one item type or another (in brooches case).

Thus, in brooches case, the author identifies five types with various variants, but in fact they are much more ${ }^{82}$. They consist of bronze brooches (see note 72 infra), a single exemplar, Thracian type brooches, a single exemplar, framed brooches, 7 exemplars, only five being complete, "spoon" type brooches, 12 exemplars, strongly profiled brooches with 14 variants. In total, 100 brooches were discovered in the settlement from Brad, the majority (70 exemplars) of bronze, the rest being made of iron (32 exemplars), a single one of silver.

12 brooch types were identified among the discoveries from Brad - brooches with frame-shaped catchplate, filiform brooches with short bilateral spring and inner chord, brooches with large bilateral spring and chord wound on the bow, "ungular" bow brooches, "spoon" type brooches (no Nauheim brooches were identified at Brad, as stated by the author ${ }^{83}$ ), strongly profiled brooches, Eastern strongly profiled brooches, brooches with zoomorphic ornaments on

\footnotetext{
${ }^{79}$ Ursachi 1995, 242-243, beside, there were identified 21 glass beads which the author includes in dress items and jewelry dated in the 1 st $\mathrm{BC}-1$ st AD.

${ }^{80}$ Ursachi 1995, 226-248.

${ }^{81}$ Ursachi 1995, 499, this is plate 203/1, bronze brooch (?) and 3, 4, 16, brooches with frame-shaped catchplate.

${ }^{82}$ Rustoiu 1997, 95-115.

${ }^{83}$ Ursachi 1995, 227.
} 
the bow, broken bow brooches, brooches with "eyes", brooches of Norico-Pannonian type with two knots on the bow, flat brooches and disk-shaped brooches.

Synthesising, the following were discovered in the settlement from Brad:

Brooches of La Tène D type. exemplars)

1. Brooches with frame-shaped catchplate ${ }^{84}$ dated during the entire $1^{\text {st }} \mathrm{BC}(2$

2. Filiform brooches, with short bilateral spring and inner chord ${ }^{85}$ dated in the second half/ end of the $1^{\text {st }} \mathrm{BC}-1^{\text {st }} \mathrm{AD}$ (until the Roman-Dacian wars), five identified exemplars.

3. Brooches with large bilateral spring and chord wound onto the bow ${ }^{86}$, variant $10 \mathrm{~b}$ being dated from the end of the $1^{\text {st }} \mathrm{BC}$ until half or third quarter of the $1^{\text {st }} \mathrm{AD}$, variant $10 \mathrm{c}$ more evolved typologically, dated in the third quarter of the $1^{\text {st }} \mathrm{AD}-2^{\text {nd }} \mathrm{AD}$, brooches are found in the catalogue description as types $\mathrm{g}, \mathrm{h}$, and $\mathrm{i}$ (6 items).

4. "Ungular" bow brooches ${ }^{87}$, the item from Brad was discovered in the last level of the settlement.

5. "Spoon" type brooches dated in the last quarter/end of the $1^{\text {st }} \mathrm{BC}$ - half/third quarter of the $1^{\text {st }} \mathrm{AD}$, the single silver-made brooch.

Roman type brooches with bilateral spring.

1. Strongly profiled brooches ${ }^{88}$ dated during the entire $1^{\text {st }} \mathrm{AD}$, five exemplars.

2. Eastern strongly profiled brooches ${ }^{89}$, variants $20 \mathrm{a}-20 \mathrm{~b}$ are dated in the second half of the $1^{\text {st }} \mathrm{BC}$ - first half of the $2^{\text {nd }} \mathrm{AD}$, variant $20 \mathrm{c}$ discovered in the last level of the settlement, the second half of the $1^{\text {st }} \mathrm{AD}$, variant $20 \mathrm{f}$ as stated by A. Rustoiu, has analogies in the Carpian environment being dated in the $2^{\text {nd }} \mathrm{AD}$.

3. Brooches with zoomorphic ornaments on the bow, initially dated during Augustus Claudius (41 - 54 AD), chronological limits being extended until Vespasian (69-79), a single exemplar.

4. "broken" bow brooches ${ }^{90}$, four discovered in levels datable by association especially with the "spoon" brooches, end of the $1^{\text {st }} \mathrm{BC}-1^{\text {st }} \mathrm{AD}$.

5. "eyed" brooches ${ }^{91}$ dated in the first or the second decade of the $1^{\text {st }} \mathrm{AD}$ until the third quarter of the same century, a single exemplar.

6. Norico-Pannonian type brooches ${ }^{92}$, variant given by Rustoiu is identified with type e6 of the catalogue, dated by the end of the $1^{\text {st }} \mathrm{BC}$ until mid $1^{\text {st }} \mathrm{AD}$.

Flat and disk-shaped brooches.

1. At Brad was identified a single exemplar framing type 31f, round brooches with anchor-shaped foot dated in the second half of the $1^{\text {st }} \mathrm{AD}$.

\footnotetext{
${ }^{84}$ Rustoiu 1997, 39, this is type 6b, brooches with outer chord and simple bow.

85 Rustoiu 1997, 42, type 9a, with circular bow in cross-section.

${ }^{86}$ Rustoiu 1997, 42-43, variants 10b, brooches with full catchplate and 10c, brooch with widened bow and foot ornamented with transversal incisions.

${ }^{87}$ Rustoiu 1997, 47-48, variant 15b, brooch with the chord wound onto the bow.

${ }^{88}$ Rustoiu 1997, 52, variant 19c, brooches with full chatchplate.

${ }^{89}$ Rustoiu 1997, 53, variants 20a, small brooches provided with two knots, of which the one from the spring is occasionally only suggested by the bow head widening, $20 \mathrm{~b}$, larger brooches provided with two well defined knots, $20 \mathrm{c}$, brooches with rhombic widened bow between the two knots, 20f, brooches without knots.

${ }^{90}$ Rustoiu 1997, 56, variant 22a, brooches with spring protected with a plate and outer chord supported by a hook and $22 \mathrm{~b}$, brooches with short bilateral spring and inner chord, at Brad being found both variants.

${ }^{91}$ Rustoiu 1997, 56, variant 23b, brooches with no "eyes" represented.

92 Rustoiu 1997, 57, variant 24a, brooches with pierced or full catchplate.
} 
Therefore, we may argue that these items are important dating elements for the $1^{\text {st }} \mathrm{BC}-$ $2^{\text {nd }} \mathrm{AD}$. The bronze brooch from the catalogue, dated in the $4^{\text {th }}-3^{\text {rd }} \mathrm{BC}$ is impossible to determine based only on the author's drawing, we also do not know to what refers the Thracian brooch presented in plates $204 / 2^{93}$ (drawing) and 328/294 (photo) and dated in the $3^{\text {rd }} \mathrm{BC}$, which is in fact the brooch with zoomorphic decoration presented above.

At Brad there were also discovered 7 iron and bronze buckles, one having a possible date in the $1^{\text {st }} \mathrm{BC}$.

\section{Coins}

29 coins were identified within the settlement from Brad, of which only 23 are identifiable, 5 are Dacian, 13 are republican and 5 imperial.

Vârteju - Bucureşti type coins (five, discovered on the acropolis) were discovered in the second Dacian level (end of the $2^{\text {nd }} \mathrm{BC}$ - beginning of the $1^{\text {st }} \mathrm{BC}$ ). Practically, only two are well preserved, of the three coins poorly preserved one being fragmentary, one is silver made, the rest being of bronze (a single item) or silvered bronze.

18 Roman coins were found (if we leave aside the 6 unidentifiable pieces $^{95}$ ), 13 are republican coins of which 5 are denarii and 5 imperial coins.

The republican coins were discovered in the last Dacian level, two pieces emerged however from the third level $\left(1^{\text {st }} \mathrm{BC}-1^{\text {st }} \mathrm{AD}\right)$. One of them, issued in $100-97 \mathrm{BC}$ is a chronological reference for dating the third layer in the $1^{\text {st }} \mathrm{BC}$, the other, issued in $48 \mathrm{BC}$, dates the defensive ditch (sic).

Republican coin issues date from the period between $82 / 81 \mathrm{BC}$ and $31 / 32 \mathrm{BC}$.

Five imperial coins were uncovered, yet since they were poorly preserved only one could be identified, a coin from Nero, the rest being hypothetically dated in the $1^{\text {st }} \mathrm{BC}-1^{\text {st }} \mathrm{AD}$ or only in the $1^{\text {st }} \mathrm{AD}$.

The catalogue also comprises the mention of two coins discovered at $2 \mathrm{~km}$ from Brad in the Carpian settlement from Călineşti village, a republican coin issued in $93 \mathrm{BC}$ and one imperial (Hadrian) issued in 134 - 138. Mentioned only informatively, they hinder the chronology of Brad settlement.

Noticeably, 15 pieces were discovered on the acropolis (the 5 coins of Vârteju type, 9 republican coins and 4 imperial coins), one coin in the uneclosed settlement ${ }^{96}$ (a republican denar) and 3 republican coins were discovered in the defensive ditch.

\section{Piroboridava (Poiana, Nicorești commune, Galați county)}

Fortified settlement of dava type (oppidum), uneclosed settlement and barrow cemetery.

\section{ANCIENT NAME} Moesia $^{97}$

Claudius Ptolemaeus (100-170 AD) - the third book of Geographia presents Dacia and

Based on Ptolemaeus records, Vasile Pârvan identifies the site from Poiana (Galați county) with ancient Piroboridava and carries first archaeological sondages in 1913.

\footnotetext{
${ }^{93}$ Ursachi $1995,499$.

94 Ursachi 1995, 561.

95 Ursachi 1995, among the 18 republican coins there is a probable Roman denar (?) very poorly preserved, no. $16,250$.

96 Ursachi 1995, 250, the findspot of an imperial coin in the unenclosed settlement is questionable, no. 20.

${ }^{97}$ Ptolemy, Geogr, III, 10, 8.
} 


\section{SITE DESCRIPTION}

The Geto-Dacian fortress from Poiana is located in the north-western limit of Poiana village, Nicoreşti commune, Galați county, on Siret River terrace. It streches over a $200 \mathrm{~m}$ high plateau including loess and sand ravines nowadays strongly affected by water erosion; only the eastern periphery is preserved from the entire site.

Archaeological research was initiated in 1926 under the supervision of R. Vulpe and continued with little interruption until 1990. The site stratigraphy comprises a succession of five inhabitancy levels; Monteoru culture (the 13th BC); the first Iron Age (Hallstatt), Basarabi culture $\left(8^{\text {th }}\right.$ c. $) ; 6^{\text {th }}-4^{\text {th }}$ c., a ThracoGetic level, the transit from the first Iron Age to the second Iron Age; La Tène $4^{\text {th }}-3^{\text {rd }} \mathrm{C}$ and $2^{\text {nd }}-1^{\text {st }} B C ; 1^{\text {st }} B C-2^{\text {nd }} A D$.

Fig. 4

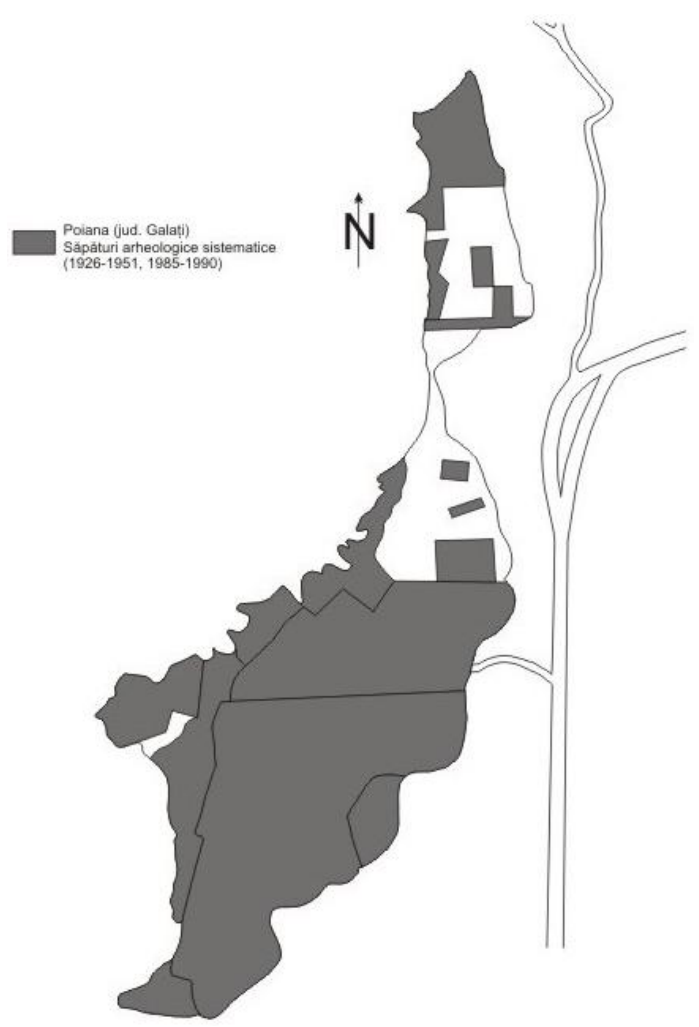

The defensive system of the fortress at Poiana is present only on the eastern and northeastern sides, consisting of rampart, palisade and defensive ditch, the promontory sharp slopes (delimiting approximately $2 / 3$ of the surface) providing natural fortification. The rampart interior was made of yellow earth (löess) coming from the promontory slopes, being reinforced by a timber palisade, the ditch delimiting the settlement only on the eastern side. The rampart was dated in the $1^{\text {st }} \mathrm{BC}$ and the beginning of the $2^{\text {nd }} \mathrm{BC}$.

\section{CATALOGUE OF DISCOVERIES}

\section{IMITATION AND IMPORTS}

Imitations (but also imports) are gathered in the catalogue of I. Glodariu's work "Relații comerciale ale Daciei cu lumea elenistică şi romană", also discussed in Dacia journal, III, IV, (1927-1932) by R. Vulpe and Ec. Vulpe. I. Glodariu's explanations and descriptions of ware types are more or less accurate, often unconvincing, however they would be considered as such.

There are imitations of red fabric bowls (end of the $2^{\text {nd }}$ - beginning of the $1^{\text {st }} \mathrm{BC}$, a single exemplar presented in I. Glodariu's catalogue) ${ }^{98}$, grey fabric bowls (two exemplars, one dated in the $1^{\text {st }} \mathrm{BC}$ and the other in the $1^{\text {st }} \mathrm{AD}$ ) and a tall bowl with shoulder (?)-end of the $1^{\text {st }} \mathrm{c}$. - beginning of the $2^{\text {nd }} \mathrm{AD}$.

Cups and pitchers ${ }^{99}$ are four in number, more specifically two pitchers, one made of red fabric and dated in the $1^{\text {st }} \mathrm{BC}$ and one made of gray fabric, with polished decoration (?) dated in the $1^{\text {st }} \mathrm{BC}-1^{\text {st }} \mathrm{AD}$. the $1^{\text {st }} \mathrm{AD}$.

The cups are one globular, dated in the $1^{\text {st }} \mathrm{BC}$ and one hand-made, dated probably in

\footnotetext{
${ }^{98}$ Glodariu 1974, 197-201; Vulpe, Vulpe 1933, 300-301.

${ }^{99}$ Glodariu 1974, 201; Vulpe, Vulpe 1933, 300.
} 
The number of Kantharos type ware ${ }^{100}$ is hard to determine, being mixed with cup type vessels; 18 exemplars could be numbered, of which one is probably fragmentary and two cups, whose dating (and even identification) are uncertain.

Four exemplars noted in the catalogue as IC38/27, IC38/28 etc. were identified based on drawings. The ware covers a period comprised between the $2^{\text {nd }} \mathrm{BC}$ and $1^{\text {st }} \mathrm{AD}$.

Alike the majority of the Geto-Dacian settlements on Siret River, the mostly spread recipient type is the amphora ${ }^{101}$, the catalogue presenting four amphoras of Thassos type with rectangular stamps (the inscription of one is illegible), seven anepigraphic amphoras (one fragmentary), the rest of the presentation comprising fragments (necks, handles, bottoms) of such recipient.

Of the four Thasos items, we chose to present three stamps important for chronology.

1. under the inscription, Herakles, standing on one knee shoots with a bow: $\Theta A \Sigma \Upsilon \Omega$ ca. $390 \mathrm{BC}$ (dated in the $3^{\text {rd }} \mathrm{BC}$ ) ${ }^{102}$.

2. a bucrane by mid inscription: $\Theta A \Sigma I \Omega N$ / MEГAK $\Lambda E I \Delta E I H \Sigma(220-180$ BC), of uncertain origin ${ }^{103}$. $\operatorname{origin}^{104}$.

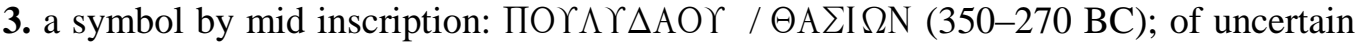

Regarding the painted pottery, the author includes within the catalogue fragments of painted ware, decorated in relief, Hellenistic and Roman fragments framed in the period $1^{\text {st }} \mathrm{BC}$ $-1^{\text {st }} \mathrm{AD}$ and a fragmentary painted vessel (?), dated with uncertainty in the $1^{\text {st }} \mathrm{AD}$.

Among ware with ornaments in relief and terra sigillata, the catalogue mentions bowls, Kantharos type vessels, cups and lamps.

The majority of the presented pottery is fragmentary and the author's presentation and study do not clearly delimit between terra sigillata and ware decorated in relief.

Hence, there are presented fragmentary ware (?) dated by the end of the $2^{\text {nd }} \mathrm{C}-$ beginning of the $1^{\text {st }} \mathrm{BC}$, Hellenistic and Italic ware $1^{\text {st }} \mathrm{BC}-1^{\text {st }} \mathrm{AD}$ (seven fragmentary exemplars and four Hellenistic and Italic exemplars), fragmentary bowls (18 exemplars of which only one is complete) dated in the $1^{\text {st }} \mathrm{BC}-1^{\text {st }} \mathrm{AD}$ and a pitcher dated in the $1^{\text {st }} \mathrm{AD}^{105}$.

Kantharos type vessels are 11 , all fragmentary, the majority being dated in the $1^{\text {st }} \mathrm{BC}-$ $1^{\mathrm{st}} \mathrm{AD}$. Five of them are painted with brown-light red lines, dated in the second half of the $1^{\text {st }} \mathrm{AD}$.

Beside the above ware, the author mentions also 14 fragmentary exemplars belonging to the cup type vessel, all of the same type, as argued, exhibiting red angoba and being dated in the $1^{\text {st }} \mathrm{BC}-1^{\text {st }} \mathrm{AD}$.

Along these examples we add a human head-shaped vessel ${ }^{106}$, worked of compact, well fired yellowish-red fabric, neck shaped as a truncated cone decorated with three circles in relief, ellipse-shaped fragmentary handle. Concerning the depiction forming the vessel's proper body, it might be either Jupiter or Dionysos, dated in the $2^{\text {nd }}-1^{\text {st }} \mathrm{BC}$.

\footnotetext{
${ }^{100}$ Glodariu 1974, 203.

${ }^{101}$ Glodariu 1974, 197-198, the author states that from approximately 200 complete and fragmentary amphoras, the majority were lost, while those still preserved are housed with the National Museum of Romanian History and the Museum from Tecuci (66 items, either complete, fragmentary or fragments are mentioned without bibliographical indications).

${ }^{102}$ Pârvan 1913, 100-102, fig. 6.

${ }^{103}$ Vulpe 1951, 167.

${ }^{104}$ Vulpe 1951, 167.

${ }^{105}$ Glodariu 1974, 210; Vulpe, Vulpe 1933, 300-310

${ }^{106}$ Sanie 1973, 419.
} 


\section{Glass}

The glass from Poiana is varied and rather much ${ }^{107}$, thus several glass ware types shall be presented below.

1. Alabastron, made by working a sandy clay core (core-made Sandkerntechnik), $2^{\text {nd }}$ $\mathrm{BC}$ - beginning of the $1^{\text {st }} \mathrm{AD}$.

2. Simple bowls, broad, modelled, end of the $2^{\text {nd }} \mathrm{BC}$ (a single exemplar), SyroPalestianian production of Hellenistic tradition.

3. Ribbed bowls made by moulding - pressing are bichrome (6 exemplars), first half of the $1^{\text {st }} \mathrm{AD}$ and monochrome (11 exemplars), $1^{\text {st }} \mathrm{AD}$.

4. Small sunken bowls (2 exemplars), $1^{\text {st }} \mathrm{AD}$.

5. Thin ribbed bowls (6 exemplars), north-Italian production ( 6 exemplars), $1^{\text {st }} \mathrm{AD}$.

6. Outer frame bowls ( 2 exemplars), Syro-Palestianian production, the second half of the $1^{\text {st }}-2^{\text {nd }} \mathrm{AD}$.

7. Cups with vertical groove ( 2 exemplars), Palestinian product, second half of the $1^{\text {st }} \mathrm{AD}$.

8. Polyfacetted decorated beaker (a single exemplar), the second half of the $1^{\text {st }} \mathrm{C}$ - first half of the $2^{\text {nd }} \mathrm{AD}$. $2^{\text {nd }} \mathrm{AD}$.

9. Beakers with flat foot and everted rim (7 exemplars), approximately half of the $1^{\text {st }}$

10. Lead-glazed cylindrical tankards "Modioli" (a single exemplar), Italian product, the second third of the $1^{\text {st }} \mathrm{AD}$.

11. Inscribed Sydonian glasses ( 3 exemplars), Syro-Palestianian production, approximately the second half of the $1^{\text {st }} \mathrm{AD}$.

12. Beakers with vegetal decoration in relief (8 exemplars), Syro-Palestianian production, the second half of the $1^{\text {st }} \mathrm{C}$ - beginning of the $2^{\text {nd }} A D$.

13. Prismatic recipients (four exemplars), Syro-Palestianian production, $1^{\text {st }} \mathrm{C}-2^{\text {nd }} A D$.

14. Unguentaria (four exemplars), second half of the $1^{\text {st }} \mathrm{C}-2^{\text {nd }} \mathrm{AD}$.

15. Plates ( 2 exemplars), second half of the $1^{\text {st }} \mathrm{AD}$.

\section{Dress items and jewelry}

Brooches

At Poiana, an important quantity of dress items and jewelry ${ }^{108}$ comprising brooches, buckels, rings, bracelets, pendants, earrings etc. was discovered.

The majority of the discovered items come from the culture layer, little being discovered in closed complexes. Between 1927 and 1990 a number of 376 brooches were found at Poiana, of which 133 are fragmentary, 71 are fragments (pins, springs, catchplates etc.) belonging to brooches and unfinished brooches (two or three exemplars) and only 172 items are complete.

According to the author, the catalogue comprises the following brooch types: Thracian types, La Tène II - III types, La Tène III - IV types, brooches with zoomorphic decoration, "spoon" type brooches (not Nauheim), Langton Down and Aucissa brooches, "soldierly" brooches, "eyed" brooches, hinged brooches ( 8 types). Unfortunately, all these types are hard to recognize based on the catalogue description ${ }^{109}$ (their description made by the beginning of the article from "Arheologia Moldovei" does not correspond with the description within the catalogue), they can be however recognized upon drawing ${ }^{110}$. A. Rustoiu's work ${ }^{111}$, presenting

\footnotetext{
${ }^{107}$ Teodor, Chiriac 1994, 183.

108 Teodor, Țau 1996, 57-105; Teodor, Țau 1997, 27-33.

109 Teodor, Țau 1996, 94-105.

${ }^{110}$ Vulpe, Teodor 2003, representation of archaeological objects made in this new monograph cancelling those inconveniences.

${ }^{111}$ Rustoiu 1997, 186, 190, 192, 195, 199, 209, 210, 211, 218, 219, 225, 227, 229.
} 
the following brooch types, proves again useful: brooches with knots, La Tène $\mathrm{C}$ type brooches, Daco-Getae types, shape-framed catchplate brooches, filiform brooches of La Tène D type with outer chord, La Tène D type brooches with inner chord, filiform brooches with short bilateral spring and inner chord, brooches with large bilateral spring and chord wound onto the bow, rhomboidal shield-shaped brooches, "spoon" type brooches, strongly profiled brooches, Eastern stongly profiled brooches, brooches with zoomorphic ornaments on the bow, brooches of Langton-Down type, Aucissa type, small wings brooches, flat brooches and disk-shaped (16 types). Among the types (except brooch fragments), 247 are in bronze, 40 are iron-made and only five are of silver (there are also four fragments pertaining to silver items).

In order to clarify the chronology of the brooches from Poiana we used the items division according to A. Rustoiu (compared with that of S. Teodor) and the following resulted:

1. Thracian type brooches

They were discovered isolated or in closed complexes, divided chronologically in the second half of the $4^{\text {th }}$ and end of the $3^{\text {rd }}$ BC. They are 23 items ${ }^{112}$, only two are silver made, the rest are of bronze ( 6 are fragmentary, one item being a fragment).

2. Brooches of La Tène $\mathrm{C}$ type $3 \mathrm{rd}-2^{\text {nd }} \mathrm{BC}$.

According to the plates and catalogue, the items of the type are $6^{113}$, of which only one exemplar is iron-made, the rest being of bronze.

Brooches with knots (bronze), variant $1 \mathrm{c}$ is present at Poiana, the item exhibits four knots, dated by the end of the $2^{\text {nd }}$ and during the $1^{\text {st }} \mathrm{BC}^{114}$ (unfortunately we could not recognize this piece even among those figured in the plates of the catalogue drafted by S. Teodor), we find it however represented with R. Vulpe ${ }^{115}$.

La Tène $\mathrm{C}$ brooches with lamellar foot, dated between the end of the $2^{\text {nd }} \mathrm{c}$. - end of the $1^{\text {st }} \mathrm{BC}$, the item present at Poiana is probably the one presented in fig. $5 / 10(?)$

3. La Tène $\mathrm{D}$ type brooches

Brooches with the frame-shaped catchplate: the item from Poiana belongs to type $6 \mathrm{a}$, having outer chord and simple spring ${ }^{116}$, dated during the entire $1^{\text {st }} \mathrm{BC}$. Brooches of the type could be recognized on the catalogue plates with fig. 6/1, 3-9, fig. 7/1-7, fig. 8/1-8, fig. 9/1-10, fig. 10/1-4 (hence, there are 37 items, 9 being complete), the majority are in iron and only two of bronze.

Filiform brooches of La Tène D type with outer chord (bronze), the item from Poiana belongs to variant $7 \mathrm{a} 1^{117}$, brooches with large bilateral spring, simple bow, type dated (in absolute chronology) between 72-25 BC.

Filiform brooches of La Tène D type with inner chord: type 8a is present at Poiana ${ }^{118}$, the bow is circular in cross-section, dated starting with the second half of the $1^{\text {st }} \mathrm{BC}$ until mid $1^{\text {st }} \mathrm{AD}$.

Filiform brooches with short bilateral spring and inner chord ("soldierly" brooches), variants $9 \mathrm{a}, 9 \mathrm{~b}^{119}$ are found at Poiana, brooches with circular bow in cross-section, fig. 6/2, fig. 10/6-7 for type 9a (their number is not certain, the majority being poorly preserved and their

\footnotetext{
112 Teodor, Țau 1996, 57, fig. 1-3, items 1-31.

113 Teodor, Țau 1996, 57, fig. 1-6, items 24-29.

${ }_{114}$ Rustoiu 1997, 31; S. Teodor, Țau 1996, 71.

${ }^{115}$ Vulpe, Vulpe 1933, 334, fig. 126/1.

${ }^{116}$ Rustoiu 1997, 39; Teodor, Țau 1996, 16-76.

${ }^{117}$ Rustoiu 1997, 40

${ }^{118}$ Rustoiu 1997, 41

${ }^{119}$ Rustoiu 1997, 42; Teodor, Țau 1996, 18.
} 
recognition is rather difficult). Variant $9 \mathrm{a}$ is dated in the second half /end of the $1^{\text {st }} \mathrm{BC}-1^{\text {st }} \mathrm{AD}$, while variant $9 b$ in the second half of the $1^{\text {st }} A D$.

Brooches with large bilateral spring and chord wound onto the bow: variants 10a and $10 \mathrm{~b}^{120}$ (bronze, iron and silver items) are present at Poiana, end of the $1^{\text {st }} \mathrm{BC}$ - until mid or third quarter of the $1^{\text {st }} \mathrm{AD}$, brooches with frame-shaped catchplate and brooches with full catchplate. Variant $10 \mathrm{~b}$ is probably represented in fig. 20/13, 26/10 (?).

Rhomboidal shield-shaped brooches ${ }^{121}$, dated in the second half of the $1^{\text {st }} \mathrm{BC}$, in the catalogue plates they are present at fig. 5/1, 2, 9, 15 .

"Spoon" type brooches, at Poiana are present three of the four types pertaining to this item, 16a, brooches with frame-shaped catchplate, 16c, brooches with full catchplate, 16d, brooches with zoomorphic and ornithomorphic ornaments or pearls on the bow.

Brooches of this type are present in the catalogue at fig. 12/1-12 and fig. 13/1-10 ${ }^{122}$, thus, a single exemplar is figured at fig. 12/14 for type 16a, type 16/d is represented by five exemplars fig. 12/3-4, 9, 12, fig. 13/2, the rest being representative for type 16 c, fig. 12/1, 2, 5$8,10,11,13$, fig. $13 / 1,3-10$.

All presented items are fragmentary or fragments, 7 exemplars are of silver (fig. 12/3, 6, $8-10$, fig. 13/3, 10), one exemplar is iron made (fig. 12/7) the rest being of bronze. Chronologically, no sequence can be inferred, however their evolution in time is slightly noticeable, type 16d being the latest manifestation of "spoon" brooches ${ }^{123}$ dated finally between the last quarter/end of the $1^{\text {st }} \mathrm{BC}$ until mid/third quarter of the $1^{\text {st }} \mathrm{AD}$.

4. Roman type brooches with bilateral spring

Strongly profiled brooches: types 19a, brooches with pierced catchplate, 19b, brooches with perforated catchplate, $19 \mathrm{c}$, brooches with full catchplate ${ }^{124}$ found in the catalogue at fig. $16-23^{125}$. Chronologically, exemplars of type $19 \mathrm{a}$ are used between the $1^{\text {st }} \mathrm{BC}$ - beginning of the $1^{\text {st }} \mathrm{AD}$, those of type $19 \mathrm{~b}$ in the first three quarters of the $1^{\text {st }} \mathrm{AD}$, type $19 \mathrm{c}$ is most numerous at Poiana, being dated in the second half of the $1^{\text {st }} \mathrm{AD}$.

Eastern strongly profiled brooches, of 6 types belonging to this type are identified variants 20a, small brooches provided with two knots, of which that from the spring is only suggested by the bow head widening, 20b, brooch provided with two well-defined knots, 20d, brooches with trapezoid foot, brooches of this type are present at fig. 16-23 of the catalogue ${ }^{126}$. Variants $20 \mathrm{a}, 20 \mathrm{~b}$, are dated starting with the end of the $1^{\text {st }} \mathrm{BC}-$ beginning of the $2^{\text {nd }} A D$, variant $20 \mathrm{~d}$ emerges by the end of the $1^{\text {st }} \mathrm{AD}$ and disappears by mid $2^{\text {nd }} \mathrm{AD}$.

Brooches with zoomorphic ornaments on the bow, brooches of the type are dated under Augustus (27 BC - 14 AD), Claudius (41-54 BC) ${ }^{127}$ until Vespasian; at Poiana a single example could be the one presented at fig. $23 / 13^{128}$.

"Eyed" brooches, the item from Poiana corresponds to variant 23a, brooches with depicted "eyes" are dated in the first or second decade of the 1st AD until the third quarter of the same century, within the catalog is represented at fig. $14 / 5^{129}$.

\footnotetext{
${ }^{120}$ Rustoiu 1997, 43; Teodor 1996, 86, 92.

${ }^{121}$ Rustoiu 1997, 44; Teodor, Țau 1996, 71.

${ }^{122}$ Rustoiu 1997, 48; Teodor, Țau 1996, 78, 79.

${ }^{123}$ Rustoiu 1997, 48-50.

${ }^{124}$ Rustoiu 1997, 52.

${ }^{125}$ Rustoiu 1997, 52, 82-89.

${ }^{126}$ Rustoiu 1997, 53, 82-89.

${ }^{127}$ Rustoiu 1997, 56.

${ }^{128}$ Teodor, Țau 1996, 89.

${ }^{129}$ Rustoiu 1997, 56-57; Teodor, Țau 1996, 80.
} 
Langton - Down type brooches, only two exemplars were discovered at Poiana, fig. $14 / 6$, and probably $20 / 6(?)$, dated between the end of the $1^{\text {st }} \mathrm{BC}$ - beginning of the second half of the $1^{\text {st }} \mathrm{AD}$.

5. Roman type hinged brooches

Brooches of Aucissa type, only one exemplar was found at Poiana, represented within the catalogue at fig. 14/4, dated from the end of the $1^{\text {st }} \mathrm{BC}$ until first half of the $1^{\text {st }} \mathrm{AD}^{130}$.

Small wings brooches, the item from Poiana corresponds to type 30a, full bow brooches, unfortunately we could not find this type within the catalogue drafted by S. Teodor, the item is however found reproduced in A. Rustoiu's work at fig. $71 / 7^{131}$, dated in the second and third quarter of the $1^{\text {st }} \mathrm{AD}$.

6. Disk-shaped flat brooches

At Poiana we may speak about two variants of this brooch type ${ }^{132}$, variant 31 a brooch in "pelta" or "lunule" shape, fig. 14/1 in the catalogue, dated during 20-50 AD, variant 31b, rhomb-shaped brooch dated in the second quarter of the $1^{\text {st }} \mathrm{AD}$ (not found within the catalogue).

We believe that variant 31c is also found at Poiana, the brooch with medallion represented in fig. 14/2, however we are not certain, A. Rustoiu does not record this type at Poiana (40-60 AD?).

Buckles and other dress items and jewelry

Several links and pins pertaining to certain buckles were identified at Poiana, dated in the period between the $3^{\text {rd }} \mathrm{BC}-2^{\text {nd }} \mathrm{AD}$. Within the catalogue drafted by $\mathrm{S}$. Teodor ${ }^{133}$, the following types are distinguished: buckles with round link, with the pin attached by bending one end $^{134}$, buckles with round link and perforated $\operatorname{pin}^{135}$, buckles with D letter-shaped link and buckles with the body in lyre shape ${ }^{136}$. These items were discovered in levels IV and V and are dated in the $3^{\text {rd }} \mathrm{BC}-2^{\text {nd }} \mathrm{AD}$.

Beside them, the inventory from Poiana also includes filiform bracelets, of torsioned wire, with groups of knobs, of wide stripe $\left(3^{\text {rd }}-2^{\text {nd }} \mathrm{BC}\right)$, rings and links, made of bronze are iron $\left(3^{\text {rd }}-1^{\text {st }} \mathrm{BC}\right)$, the author does not however record the golden ring with sardonyx cameo $\left(1^{\text {st }} \mathrm{BC}\right.$ ?).

Beside the above, we note the mirrors $\left(2^{\text {nd }}-1^{\text {st }} \mathrm{BC}\right)$, pins, beads, pendants, etc.

\section{Coins}

Compared to the other settlements on Siret River, the coins from Poiana were identified in largest quantities, 6 hoards comprising Roman coins being discovered from 1928 until 1950 together with a hoard of Greek, Callatis type coins (1985) $\left(3^{\text {rd }} \mathrm{c} \text {. }- \text { second half of the } 1^{\text {st }} \mathrm{BC}\right)^{137}$ and the seventh hoard of Roman coins ${ }^{138}$ found in 1987 , to which we add isolated coins found within excavations.

The first hoard consisting of 152 pieces framed chronologically between 165-155 BC 14-12 BC under emperor Augustus was found in 1928, the second was identified in 1938 containing 82 pieces, the latest coin is however not mentioned, the most recent being still from emperor Augustus; the third hoard of 25 pieces was discovered during the same year, its chronological framing is yet lacking, the fourth hoard was found in 1949 and comprises 35

\footnotetext{
${ }^{130}$ Rustoiu 1997, 60, 80.

${ }^{131}$ Rustoiu 1997, 60-61, 227.

${ }^{132}$ Rustoiu 1997, 61-62; Teodor, Țau 1996, 80.

${ }^{133}$ Teodor 1997, 27-88.

${ }^{134}$ Teodor 1997, 48, fig. 15/2, 9, 13, 18.

135 Teodor 1997, 48, fig. 15/1.

${ }^{136}$ Teodor 1997 , 48, fig. $15 / 20$.

${ }^{137}$ Teodor, Nicu, Țau 1987, 133-137.

${ }^{138}$ Teodor, Mihăilescu-Bîrliba 1993, 121-132.
} 
pieces, framed chronologically between $135-148 \mathrm{BC}-2 \mathrm{BC}$; in 1950 two other hoards were identified, the first of 194 pieces, 155-150 BC - 12-11 BC (Augustus) and the second of 66 pieces, 137-136 BC - (Vespasian 69-79 AD). The last hoard was discovered in 1987 and consists of only 6 pieces, $2^{\text {nd }}$ c. $\mathrm{BC}-75 \mathrm{BC}$ (three republican coins, one being an issue from Marcus Antonius and four imperial issues, one from Augustus and three from Vespasian).

The hoard of Callatis pieces comprises 32 coins of which 5 are of brass and 27 are of bronze ( 2 coins seem to have been gilded), they belong to the type which exhibits on the obverse the head of god Apollo and the tripod with spike on the reverse, dated from Lysimachus's death in $281 \mathrm{BC}$ until the defeat of Mithradates VI Eupator by the Romans in 72 BC. The Greek coins start with Histrian coin issues, $4^{\text {th }}-3^{\text {rd }} B C^{139}$.

The Geto-Dacian coins, copies of Macedonian ones, were not discovered in large numbers, being of Huşi Vovrieşti type ( 1 coin, $\left.3^{\text {rd }}-2^{\text {nd }} B C\right)$, Inoteşti-Răcoasa ( 2 coins, $\left.2^{\text {nd }} B C\right)$, Adâncata Mănăstioara (1 coin, $\left.2^{\text {nd }} \mathrm{BC}\right)$, Vârteju Bucureşti (5 coins, second half of the $2^{\text {nd }} \mathrm{BC}$ ), also coins from Apollonia (1 item) and Dyrrachium (2 items) $2^{\text {nd }} \mathrm{BC}^{140}$.

Regarding isolated coins, we shall present 18 published coins ${ }^{141}$ of which 11 are republican and imperial Roman coins (among them, 2 are issues from Augustus (27 BC - 14 AD), 1 from Tiberius (14-37 AD), 5 from Vespasian (69-79), 1 from Antoninus Pius (138161), 1 from Elagabalus (218-222) and 1 from Rhometalces I (11 BC - 12 AD).

\section{Tamasidava (Răcătău, Horgeşti commune, Bacău county)}

Fortified settlement of dava type (oppidum), barrow cemetery

\section{ANCIENT NAME}

Claudius Ptolemaeus (100-170 AD) - the third book of Geographia presents Dacia and Moesia $^{142}$.

Based on Ptolemaeus records, the fortified settlement from Răcătău was hypothetically identified with ancient Tamasidava.

First information on this site is found with Alexandru Odobescu in Chestionarul către învățători (1871-1873).

The general plan of the excavations is lacking, the site has no topographical plan.

\section{SITE DESCRIPTION}

The site from Răcătău is located on the left bank of Siret River, known under the toponym "Cetăţuia" (Dealul Şoimului). Under king Burebista (?) a strong fortification consisting of a defensive ditch and palisade was erected. The settlement is deserted by the end of the $1^{\text {st }}$ millennium BC.

Archaeological investigations were initiated in 1968 by the team including V. Căpitanu and V. Ursachi; they progressed intermittently over 28 campaigns until 1997.

A fortification (defensive ditch and palisade) of "oppidum" type was identified on the acropolis, the unenclosed settlement $\left(1^{\text {st }} \mathrm{BC}-1^{\text {st }} \mathrm{AD}\right)$ being located close to it. Archaeological research was also carried out in the barrow cemetery located on the territory of Pâncești commune (Dealul Odăilor) at approximately $1 \mathrm{~km}$ from the settlement at Răcătău. The settlement was inhabited starting with the $4^{\text {th }} \mathrm{C}$, being probably deserted in the $1^{\text {st }} \mathrm{AD}$.

\footnotetext{
${ }^{139}$ Mitrea 1981, 121-123.

${ }^{140}$ Teodor, Bârliba 1993, 121; Preda 1973, 120, 165, 238.

${ }^{141}$ Teodor 1993, 121-132.

${ }^{142}$ Ptolemy, Geografia, III, 8, 4.
} 


\section{CATALOGUE OF DISCOVERIES}

\section{IMITATION AND IMPORTS}

Imitations and imports are not separately tackled, while imports are found disparately within articles dealing with the settlement from Răcătău.

At Răcătău, imitations of Kantharos type ware with polished or painted decoration are numerous, 22 variants being discovered according to the author's typology ${ }^{143}$. Unfortunately the author does not provide a chronological framing of such ware, but we know however, based on his descriptions and drawings, that many are dated in the $1^{\text {st }} \mathrm{BC}-1^{\text {st }} \mathrm{AD}$, in general this vessel type being framed between the $5^{\text {th }}$ and $1^{\text {st }} \mathrm{BC}$.

We add imitations after the Krater-type Greek vessel, also divided in 6 types, dated in the $1^{\text {st }} \mathrm{BC}-1^{\text {st }} \mathrm{AD}^{144}$.

In the case of Delian cup imitations, the number of discovered fragments is uncertain, we may note, however an almost complete exemplar ${ }^{145}$.

The amphora, especially the Cos and pseudo-Cos amphora ranks first among imports and is present in all site reports on the settlement from Răcătău. Thus, among fragments and restorable items we mention a single stamped exemplar ${ }^{146}$ (insofar quoted), are dated in the $3^{\text {rd }}-$ $2^{\text {nd }} \mathrm{BC}$, Cos amphoras with bifid handles are dated in the $2^{\text {nd }}-1^{\text {st }} \mathrm{BC}$, while those with globular body in the $1^{\text {st }} \mathrm{BC}-1^{\text {st }} \mathrm{AD}$, pyriform and fusiform amphoras.

There are 6 stamped amphoras ${ }^{147}$, however only one is complete, i.e. an amphora (tituli picti) with globular body and conical base, dated in the $1^{\text {st }} \mathrm{BC}-1^{\text {st }} \mathrm{AD}$.

In addition, we note as chronological element for the $4^{\text {th }}-3^{\text {rd }} \mathrm{BC}$, a Heracleia Pontica type amphora with stamp ${ }^{148}$.

Greek and Roman imports are numerous and as previously stated, 90\% are in Moldova only, $70 \%$ of this percentage being represented by Brad, Răcătău and Poiana settlements. Unfortunately, import ware is not systematised within a catalogue (alike the one on Brad, for instance), thus neither all import ware types nor their numbers are known. We also add that stratigraphy does not help in ascertaining the find context of the import ware either.

The presence of terra sigillata is entirely accepted in the majority of the davas we are dealing with, however concerning Răcătău little reference is made on this ware type.

Thus, we may only assume that a certain percentage of Kantharos type ware with red and black angoba is represented by terra sigillata, the imports being dated in the $1^{\text {st }} \mathrm{BC}-1^{\text {st }} \mathrm{AD}$.

Beside numerous vessel types like cups, bowls, dishes we note the Boscoreale cups, the settlement from Răcătău being the second after Barboşi where vessels of this type dated in the $1^{\text {st }} \mathrm{BC}-1^{\text {st }} \mathrm{AD}$ were uncovered; Delian cups $\left(1^{\mathrm{st}} \mathrm{BC}-1^{\text {st }} \mathrm{AD}\right)$, oenochoe-type vessels $\left(1^{\text {st }} \mathrm{BC}\right)$, Krater vessels $\left(1^{\text {st }} \mathrm{BC}-1^{\text {st }} \mathrm{AD}\right)$, the black glaze ware represented by a plate, box-lamps with 7 nozzles, dated in the interval from the beginning of emperor Augustus period (27 BC - 14 AD) until the end of the $1^{\text {st }} \mathrm{AD}^{149}$, Skyphos type ware discovered during the 1991 campaign (the vessel depicts a nude scene) being dated by the end of the $1^{\text {st }} \mathrm{BC}$ - first half of the $1^{\text {st }} \mathrm{AD}^{150}$.

\footnotetext{
${ }^{143}$ Căpitanu 1986-1987, 140.

${ }^{144}$ Căpitanu 1986-1987, 144-145.

${ }^{145}$ Căpitanu 1980, fig. 9/10, 208; Căpitanu 1997, 50-118.

${ }^{146}$ Căpitanu 1976, 49-71.

${ }^{147}$ Căpitanu 1985, 75-80.

148 Căpitanu 1985, 52.

149 Căpitanu 1992, 140-141.

150 Căpitanu 1992, 146.
} 
From 1991 until 1997, the number of import ware (and not only) increased very much according to site reports ${ }^{151}$, however no statistics was drafted insofar. The material from Răcătău is very rich yet its examination remains an aim.

\section{Glass}

Like the pottery, the discovery of glass ware ${ }^{152}$ is not systematised either, the single davas which were classified, catalogued and typologised being Poiana, Barboşi and Brad. Quantitatively, it seems that glass products exceed those from Barboşi and Brad, varied shapes being identified like cups, beakers, bowls and unguentaria.

Thus, there were uncovered millefiori-mosaic type vessels, $1^{\text {st }} \mathrm{BC}-1^{\text {st }} \mathrm{AD}$, a beaker decorated with lotus sprouts made by moulding, item of Eastern origin, probably part of the ware category with vegetal decoration manufactured by Syro-Palestinian workshops, dated in the second half of the $1^{\text {st }} \mathrm{C}$ - beginning of the $2^{\text {nd }} \mathrm{AD}$.

In addition, there were discovered fragments belonging to bowl type vessels, ornamented with fines and ribs dated in the $1^{\text {st }} \mathrm{AD}$. The author does not mention the number of bichrome (first half of the $1^{\text {st }} \mathrm{AD}$ ) and monochrome exemplars for a more precise chronological framing.

\section{Dress items and jewelry}

Brooches

In 1989 , a catalogue ${ }^{153}$ of jewelry and dress items, except brooches ${ }^{154}$ was drafted, wherein the author noted the discovery of two necklaces, four bracelets, two diadems, silver and bronze earring, links, pendants, however the catalogue is deficient regarding their dating.

The brooches were presented in a catalogue from 1984 and eight types identified in the settlement from Răcătău were mentioned; Thracian brooches (3), "spoon" type brooches (27), brooches with short bilateral spring (8), brooches with large bilateral spring (4), strongly profiled brooches (2), shaped body brooches (34 exemplars, 12, brooches with simple body sic!), Aucissa brooches (1 exemplar discovered in a closed complex), brooches with "eyes"(1).

This catalogue changes radically when confronting the items (drawings) presented by V. Căpitanu with those from the catalogue, also with the aid of the specialty work of A. Rustoiu ${ }^{155}$.

There are three Thracian brooches of which one was undergoing processing, one is in silver, the rest being of bronze. The description provided by the author (together with their preservation state) do not ascertain their Thracian character, however until further explanations, we shall consider them as such; dated between the end of the $4^{\text {th }} \mathrm{BC}$ and the first half of the $3^{\text {rd }}$ BC. Also framed within same period is a Celtic type brooch, without supplemental information ${ }^{156}$.

According to Rustoiu's framing, the following brooch types come from Răcătău:

1. La Tène $\mathrm{D}$ brooches

La Tène D brooches with inner chord (4), variants $8 \mathrm{a}$, brooches with circular bow in cross-section, $8 \mathrm{~b}$, brooches with flat bow, dated in the second half of the $1^{\text {st }} \mathrm{BC}$ until mid $1^{\text {st }}$ $\mathrm{AD}^{157}$.

\footnotetext{
${ }^{151}$ Căpitanu 1997, 50-118.

${ }^{152}$ Căpitanu 1997, 49-71.

${ }^{153}$ Căpitanu 1989, 97-124.

${ }^{154}$ Căpitanu 1984, 59-84.

${ }^{155}$ Rustoiu 1997, 95-115.

${ }^{156}$ Căpitanu 1976, 49-71.

${ }^{157}$ Rustoiu 1997, 41, 102-103; Rustoiu 1997, 49-71, fig. 5/4, 9, 10, 8/10.
} 
Filiform brooches with short bilateral spring and inner chord ("soldierly" brooches - 3), variant $9 \mathrm{a}$, brooches with circular bow in cross-section, dated in the second half/end of the $1^{\text {st }}$ $\mathrm{BC}-1^{\text {st }} \mathrm{AD}$ (until the Daco-Roman wars) ${ }^{158}$.

Brooches with large bilateral spring and chord wound onto the bow $(8$, silver and bronze, variants $10 \mathrm{~b}$, brooches with full catchplate (end of the $1^{\text {st }} \mathrm{BC}-\mathrm{mid} /$ third quarter of the $1^{\text {st }} \mathrm{AD}$ ), 10c, brooches with widened bow and foot ornamented with transversal incisions (the third quarter of the $\left.1^{\text {st }} \mathrm{C}-2^{\text {nd }} \mathrm{AD}\right)^{159}$.

"Spoon" type brooches (23, silver and bronze), variants 16a, frame-shaped catchplate brooches, 16c, full catchplate brooches, 16d, brooches with the bow ornamented with zoomorphic, ornitomorphic ornaments or pearls. It may be noticed that this brooch type was found rather in large quantities, exceeding the number of the items discovered in the other settlements on Siret River. Variants 16a and 16c are dated in the last quarter / end of the $1^{\text {st }} \mathrm{BC}$ - mid / third quarter of the $1^{\text {st }} \mathrm{AD}$, while type $16 \mathrm{~d}$ dates from the first half of the $1^{\text {st }} \mathrm{AD}$ until the third quarter of the same century ${ }^{160}$.

2. Roman type brooches with bilateral spring

Strongly profiled brooches (9), variants $19 \mathrm{a}$, brooches with pierced catchplate, $1^{\text {st }} \mathrm{BC}-$ beginning of the $1^{\text {st }} \mathrm{AD}, 19 \mathrm{~b}$., perforated catchplate brooches, first three quarters of the $1^{\text {st }} \mathrm{AD}$, full catchplate brooches, the second half of the $1^{\text {st }} \mathrm{AD}^{161}$.

Eastern strongly profiled brooches (22), variants 20a, small brooches provided with two knots, of which that from the spring is occasionally only suggested by the head widening, dated starting with the end of the $1^{\text {st }} \mathrm{C}$ - beginning of the $2^{\text {nd }} A D, 20 \mathrm{~b}$ brooches larger than variant 20a, provided with two well-defined knots, same dating ${ }^{162}$.

Brooches with zoomorphic ornaments on the bow, a single exemplar found in the settlement from Răcătău, dated in under Augustus-Claudius until Vespasian ${ }^{163}$.

Brooches with "eyes", variant 23a, brooches with depicted "eyes", dated in the first or second decade of the $1^{\text {st }} \mathrm{BC}$ until the third quarter of the $1^{\text {st }} \mathrm{AD}^{164}$.

3. Hinged Roman type brooches $\mathrm{AD}^{165}$

Aucissa brooches, at Răcătău a single exemplar was found, $1^{\text {st }} \mathrm{BC}$ - first half of the $1^{\text {st }}$

Small wings brooches, variant 30a, brooches with full bow are dated in the second and third quarter of the $1^{\text {st }} \mathrm{AD}^{166}$.

4. Disk-shaped flat brooches

Zoomorphic brooches ${ }^{167}$ (variant $31 \mathrm{~g}$ ), the item is in the shape of a dove, hinged fastening system, chronologically framed in the second half of the $1^{\text {st }} \mathrm{AD}$.

The number of the exemplars is not definitive for each category, the items resulted from the excavations of 1990-1997 are not included, thus we may add another two exemplars pertaining to the "spoon" type brooch ${ }^{168}$. The same is valid for pottery, while the drafting of a pottery catalogue with adequate typology would largely clarify quantities and chronologies.

\footnotetext{
${ }^{158}$ Rustoiu 1997, 42, 103-104; 66, fig. 5/1-3.

${ }^{159}$ Rustoiu 1997, 42, 105-106; 50, fig. 4/6, 6/12, 7/1-3, 9/4, 6/8.

${ }^{160}$ Rustoiu 1997, 48-50, 108-109; 49-71, fig. 1/4-13, 2/1-6, 3/1-6, 10/11.

${ }^{161}$ Rustoiu 1997, 52-53, 111; 49-71, fig. 4/1-5, 8-9, 6/1-2.

${ }^{162}$ Rustoiu 1997, 55-56, 113; 49-71, fig. 4/7, 6/1-11, 8/1-9, 9/1-2.

163 Rustoiu 1997, 56, 113; Căpitanu 1989, 120, fig. 10/4.

${ }^{164}$ Rustoiu 1997, 56-57, 113; Căpitanu 1976, 49-71, fig. 9/7.

165 Rustoiu 1997, 66, 115; Căpitanu 1976, 49-71, fig. 9/10.

${ }^{166}$ Rustoiu 1997, 60-61, 227; Căpitanu 1989, 120, fig. 9/13.

${ }^{167}$ Rustoiu 1997, 229, fig. 73/11, the item is not framed in the catalogue drafted by Căpitanu 1976.

168 Căpitanu 1997, 50-118.
} 


\section{Coins}

Within the excavation from Răcătău 29 coins were uncovered ${ }^{169}$ of which 19 are republican denarii, 4 are issues from Tiberius, Claudius and Nero, and 2 coins are of VârtejuBucureşti type (end of the $2^{\text {nd }} \mathrm{C}$ - beginning of the $1^{\text {st }} \mathrm{BC}$ ).

Two Roman coin hoards were also identified, the first, amounting to 71 Roman republican and imperial coins and covering a period between $150 \mathrm{BC}$ (M. Baebius Tampilus) and 8-6 BC under Augustus, was discovered in 1969. Three pieces are copies, while the last coin is an issue from Juba $\mathrm{I}$.

In the same year, at Pânceşti ${ }^{170}$ (site named Dealul Odăilor at $2 \mathrm{~km}$ from Răcătău) was discovered a hoard comprising 202 pieces including republican and imperial denarii, commencing from 172-151 BC (Atilius Saranus) until Tiberius 14-15. At Răcătău, 68 pieces representing denarii from Tampilus (155-150 BC) until Juba I (60-40 BC) were uncovered, among them, three are copies of Roman denarii.

The second hoard ${ }^{171}$ from Răcătău comprises 55 items and frames within the period between 137-39 BC, the last issues being from Marcus Antonius and Augustus 41 BC, 27 BC $14 \mathrm{AD}$, with only two copies.

\section{CONCLUSIONS}

Based on the material published within specialty journals or monographs and analysed herein, we attempted to overview the archaeological material for each of the examined settlements ${ }^{172}$, in our attempt to determine chronological sequences for each settlement.

Thus, we took under consideration chronologically sensitive materials, the analysis being based mainly on imports and imitations, dress items and jewelry (brooches, buckles etc.), coins and less, local ware.

The most intriguing issue is the establishment of the end of each settlement, however, the coins, considered important dating elements within restricted limits, cannot be considered but a postquem reference. In fact, it was agreed that each coin had a circulation period of two up to three decades and therefore, we cannot rely on coins when dating the last inhabitancy level.

Thus, for each settlement, the last coin is as follows:

Barboși ${ }^{173}$, issue from emperor Vespasian (69-71);

$\mathrm{Brad}^{174}$, issue from emperor Nero (54-68);

Poiana ${ }^{175}$, oldest coins are from emperors Antoninus-Pius (138-161) and Elagabalus (218-229);

Răcătău ${ }^{176}$, last coin issue is from emperor Nero (54-68).

We also add that Roman coin hoards ${ }^{177}$ were discovered at Barboşi (2), Poiana (7, the last being found in 1997) and 2 at Răcătău.

Very few Geto-Dacian coins were discovered ${ }^{178}$, the majority coming from Poiana, 13, then Brad 5 and Răcătău 2, Vârteju-Bucureşti coins dominating (second half of the $2^{\text {nd }} \mathrm{BC}$ ).

\footnotetext{
${ }^{169}$ Căpitanu, Ursachi 1975, 45-52.

${ }^{170}$ Căpitanu 1971, 162-164.

${ }^{171}$ Căpitanu, Ursachi 1975, 42-52.

${ }^{172}$ See tables by the end of the study.

${ }^{173}$ Sanie, Şeiva Sanie 1991, 45-55.

${ }^{174}$ Ursachi 1985, 250.

175 Teodor, Bârliba 1993, 121.

${ }^{176}$ Căpitanu, Ursachi 1972, 97-114; 1975, 45-52.

${ }^{177}$ See pl. 3.

${ }^{178}$ See pl. 3 .
} 
In addition, West-Pontic coin issues are represented only at Barboşi where Histrian and Tomis issues are known and at Poiana, where beside Histrian issues, a hoard comprising 32 Callatian coins was discovered.

We notice that Greek and Geto-Dacian coins are poorly represented within the settlements on Siret River, 22 compared to only 133 discovered at Cârlomăneşti ${ }^{179}$, for instance.

The Geto-Dacian coin is replaced by republican and imperial denarii, well represented through isolated finds and hoards. Noticeably, the period comprised between emperor Augustus (27 BC - $14 \mathrm{AD}$ ) and emperor Vespasianus (69-79) is well represented by coin quantities comprised especially within hoards.

The dress items and jewelry ${ }^{180}$ (i.e. brooches) have, alike the coins, several distinct phases, being more accurate dating elements ${ }^{181}$. In each settlement on Siret River, the brooch is well represented.

Within discoveries, three distinct development phases may be observed: Thracian brooches are best represented at Poiana and Brad, while at Răcătău they are uncertain; La Tène C and D type brooches ${ }^{182}$, well represented at Poiana, Brad and Răcătău and less at Barboşi; Roman type brooches replacing La Tène brooches (with bilateral spring and hinge), represented at Barboşi, Brad, Poiana and Răcătău. We add disk brooches in the settlements from Poiana and Brad and Aucissa type brooches only at Poiana and Răcătău ${ }^{183}$.

Important dating elements are also found in the case of certain ware types, however as already mentioned, pottery is poorly tackled within publications.

In the case of the Geto-Dacian ware, several changes may be noticed. Thus, certain pottery types disappear, especially the black polished pottery worked by the hand-modelling of the fabric, starting with the $1^{\text {st }} \mathrm{AD}$, while wheel-made ware, especially the painted pottery, peaks in the $1^{\text {st }} \mathrm{AD}$.

Concerning the imports, we mention the importance of Delian cups ${ }^{184}$ (either Getic or Greek) as dating elements covering the period of the $2^{\text {nd }} / 1^{\text {st }} \mathrm{BC}-1^{\text {st }} \mathrm{AD}$, exemplars of this vessel type being discovered only at Brad, Răcătău, Poiana and Barboşi.

The settlement from Barboşi is founded probably in the $3^{\text {rd }}-2^{\text {nd }} \mathrm{BC}$ and most likely, ceases to exist following the actions of Tib. Plautius Silvanus Aelianus (57-67 AD), governor of Moesia, in the regions north the Danube, whose result was the forced dislocation of 100.000 trans-Danubians south the Danube ${ }^{185}$. Within the settlement at Poiana, oldest deposits are from the $5^{\text {th }}-4^{\text {th }} \mathrm{BC}$, being finally deserted by mid $2^{\text {nd }}-$ beginning of the $3^{\text {rd }} \mathrm{AD}$.

The settlements from Brad and Răcătău are established in the $4^{\text {th }} \mathrm{BC}$, while their end is probably related to the Daco-Roman wars ${ }^{186}$.

\footnotetext{
${ }^{179}$ Babeş 1975, 130.

${ }^{180}$ See pl. 2.

${ }^{181}$ On the evolution of brooches discovered in the settlements on Siret River, see plates I, II, III.

${ }^{182}$ Fig. 1 and 2.

${ }^{183}$ Fig. 3.

${ }^{184}$ See pl. 4

${ }^{185}$ Following the archaeological investigation performed by Gostar and Sanie, a destruction level that may be related to these events was found.

${ }^{186}$ Certain brooch categories (brooches with large bilateral spring and chord wound onto the bow or Eastern strongly profiled brooches) continue chronologically until the third quarter/ second half of the 2 nd AD.
} 


\begin{tabular}{|l|c|c|c|c|c|c|}
\hline \multicolumn{1}{|c|}{ Coins } & $\begin{array}{c}\text { Geto- } \\
\text { Dacian }\end{array}$ & $\begin{array}{c}\text { Histria, } \\
\text { Tomis }\end{array}$ & Thasos & Dyrachium & Callatis & $\begin{array}{c}\text { Republican } \\
\text { and imperial } \\
\text { Roman denari }\end{array}$ \\
\hline Geto-Dacian & XXXX & 1 & 1 & 1 & 1 & 4 \\
\hline Histria, Tomis & 1 & XXXXXXX & - & - & - & 1 \\
\hline Thasos & 1 & - & XXXXX & 1 & 1 & 1 \\
\hline Dyrachium & 1 & - & 1 & XXXXXXX & 1 & 1 \\
\hline Callatis & 1 & - & 1 & 1 & XXXX & 1 \\
\hline $\begin{array}{l}\text { Republican } \\
\text { and imperial } \\
\text { Roman denarii }\end{array}$ & 4 & 1 & 1 & 1 & 1 & $\begin{array}{c}\text { XXXXXXX } \\
\text { XXXXXX } \\
\text { XXXXX } \\
\text { XXXX }\end{array}$ \\
\hline
\end{tabular}

\begin{tabular}{|c|c|c|c|c|}
\hline $\begin{array}{c}\text { Archaeological items } \\
\text { Chronological reference } \\
\text { point }\end{array}$ & & & & \\
\hline Date of the last coin & $\begin{array}{c}\text { Vespasian } \\
(69-71)\end{array}$ & $\begin{array}{l}\text { Nero } \\
(54-68)\end{array}$ & $\begin{array}{c}\text { Antonius-Pius (138-161) } \\
\text { and Elagabalus (218- } \\
\text { 229) }\end{array}$ & $\begin{array}{l}\text { Nero } \\
57 \mathrm{AD}\end{array}$ \\
\hline Strongly profiled brooches & & & & \\
\hline Aucissa brooches & & & & \\
\hline Imperial coins & & & & \\
\hline Republican coins & & & & \\
\hline Painted pottery & & & & \\
\hline Delian/Megarian cups & & & & \\
\hline Geto-Dacian coins & & & & \\
\hline Greek coins & & & & \\
\hline La Tène II & & & & \\
\hline Thracian brooches & & & & \\
\hline DAVA & Barboşi & Brad & Poiana & Răcătău \\
\hline
\end{tabular}

\section{BIBLIOGRAPHY}

Babeş 1975 - M. Babeş, Problèmes de la chronologie de la culture Gèto-Dace à la lumière des fouilles de Cârlomăneşti, Dacia N.S. 19, 125-139.

Babeş 2000 - M. Babeş, La conquête trajane vue par l'archéologie, Civilisation greque et cultures antiques périphériques, Bucarest, 323-338. 
Căpitanu 1969 - V. Căpitanu, O nouă cetăție dacică pe Valea Siretului, Carpica 2, 93-130.

Căpitanu 1971 - V. Căpitanu, Două tezaure de denari romani republicani şi imperiali descoperite la Răcătău şi Pânceşti, Carpica 4, 162-164.

Căpitanu, Ursachi 1972 - V. Căpitanu, V. Ursachi, Descoperiri geto-dacice în județul Bacău, Crisia 2, 97-114.

Căpitanu, Ursachi 1975 - V. Căpitanu, V. Ursachi, Noi tezaure de monede antice (jud. Bacău), Carpica 8, 45-52.

Căpitanu 1976 - V. Căpitanu, Săpături arheologice în dava de la Răcătău, Carpica 8, 49-71.

Căpitanu 1984 - V. Căpitanu, Fibule descoperite în aşezarea de tip dava de la Răcătău, Carpica 16, 59-84.

Căpitanu 1985 - V. Căpitanu, Amfore cu inscripții descoperite în dava de la Răcătău, Carpica 17, 75-80.

Căpitanu 1987 - V. Căpitanu, Ceramica geto-dacică de la Răcătău, Carpica 18-19, 103-214.

Căpitanu 1989 - V. Căpitanu, Obiecte de podoabă şi piese vestimentare descoperite la Răcătău, Carpica 20, 97-124.

Căpitanu 1992 - V. Căpitanu, Noi contribuții la cunoaşterea civilizației geto-dace în bazinul Siretului mijlociu, cetatea dacică de la Răcătău (Antica Tamasidava), Carpica 22, 131-147.

Căpitanu 1993 - V. Căpitanu, Cercetările arheologice în dava de la Răcătău-Tamasidava, Carpica 26, 50-118.

Chițescu 1971 - M. Chițescu, Câteva tezaure monetare romane reprezentative din Moldova, Carpica 4, 161.

Crişan 1969 - I. H. Crişan, Ceramica daco-getică. Cu specială privire la Transilvania, Bucureşti.

Collis 2003 - J. Collis, The European Iron Age, London and New York.

Florescu 1971 - M. Florescu, Unele considerații asupra cetăților traco-getice (hallstattiene) din mileniul I a. Chr. de pe teritoriul Moldovei, CI 2, 103-118.

Glodariu 1974 - I. Glodariu, Relaţiile comerciale ale Daciei cu lumea elenistică şi romană, Cluj.

Gostar 1962 - N. Gostar, Săpăturile şi sondajele de la Şendreni-Barboşi, MCA 8, 507-509.

Gostar 1965 - N. Gostar, Cetățile dacice din Moldova, Apulum 5, 144-147.

Gostar 1969 - N. Gostar, Cetățile dacice din Moldova, Bucureşti.

Harris 1979 - E. C. Harris, The Laws of archaeological stratigraphy, World Archaeology 11, 111-117.

Jockey 1999 - P. Jockey, L'archéologie, Paris, 241-252.

Horedt 1973 - K. Horedt, Die Dakischen Silberfunde, Dacia N.S. 17, 127-167.

Horedt 1976 - K. Horedt, Fragen der dakischen Latènechronologie, TD 1, 127-130.

Mitrea 1981 - B. Mitrea, Etape cronologice în relațiile Histriei cu geto-dacii pe baza monedelor, TD 5, $1-2,121-123$.

Moscalu 1983 - E. Moscalu, Ceramica traco-getică, Bucureşti.

Müller 1883 - C. Müller Claudii Ptolemei Geographia, I, 1, Paris.

Rustoiu 1997 - A. Rustoiu, Fibulele din Dacia preromană (sec.II î.e.n.-I e.n), Biblioteca.Thracologica XXII.

Pârvan 1913 - V. Pârvan, Castrul de la Poiana şi drumul roman prin Moldova de Jos, ARMSI II, 35, 106-111.

Pârvan 1974 - V. Pârvan, Începuturile vieții romane la gurile Dunării (ed. R. Vulpe), Bucureşti.

Pârvan 1926 - V. Pârvan, Getica. O protoistorie a Daciei, Bucureşti.

Rachet 1978 - G. Rachet, Universul arheologiei, Bucureşti.

Roskams 2001 - S. Roskams, Excavation - Cambridge Manuals in Archaeology, Cambridge.

Rustoiu 1997 - A. Rustoiu, Fibule din Dacia preromană, Bucureşti.

Sanie 1974 - S. Sanie, Importuri elenistice şi romane în câteva cetăți şi aşezări getice din Moldova, SCIV 24, 3, 407-434.

Sanie 1981 - S. Sanie, Civilizația romană la est de Carpaţi şi romanitatea pe teritoriul Moldovei (sec II î.H - III d.H), Iaşi.

Sanie 1983 - S. Sanie, Unele considerații asupra cetății dacice de la Barboşi, SAA 1, 141-151.

Sanie 1987 - S. Sanie, Cetăţuia geto-dacică de la Barboşi I, AM 11, 101-111.

Sanie 1988 - S. Sanie, Cetăţuia geto-dacică de la Barboşi II, AM 12, 53-103.

Sanie, Sanie 1991 - S. Sanie, Ş. Sanie, Cetățuia geto-dacică de la Barboşi III, AM 14, 45-55. 
Sanie, Sanie 1992 - S. Sanie, Ş. Sanie, Cetăţuia geto-dacică de la Barboşi IV, AM 15, 71-96.

Ştefan 1938 - Gh. Ştefan, Nouvelles découvertes dans le "Castellum” romain de Barboşi, Dacia 5-6, 341-349.

Tătulea, Vicoveanu 1973 - C. Tătulea, D. Vicoveanu, Depozitul de piese de cult de la Poiana, CI 3, 45-57.

Teodor 1989 - S. Teodor, Civilizația geto-dacică la est de Carpați. Considerații topografice, Symposia Thracologica 7, Tulcea, 115-125.

Teodor 1992 - S. Teodor, Importuri greceşti la Piroboridava, Symposia Thracologica, 9, Băile Herculane.

Teodor 1993 - S. Teodor, L'espace est carpatique aux $V^{e}-I I I^{e}$, siecle av. n.è, Actes du XII Congrès International des Sciences Prehistorique et Protohistorique, 2, Bratislava, 275-281.

Teodor 1993 - S. Teodor, Stratigrafia stațiunii arheologice de la Poiana, Carpica 13, 1, 115-124.

Teodor 1994 - S. Teodor, Ceramica de import din aşezarea geto-dacică de la Poiana, jud. Galați, Carpica 25, 73-122.

Teodor 1995 - S. Teodor, La ceramique peinte de l'ètablissement gèto-dace de Poiana-Tecuci, TD 16, 1-2, 199-210.

Teodor 1999 - S. Teodor, Regiunile est-carpatice ale României în sec. V-II a. Chr. Considerații generale şi repertoriu arheologic, Bucureşti.

Teodor 1999 - S. Teodor, Corps à éclairer gèto-daces, TD 20, 1-2, 205-216.

Teodor, Mihăilescu-Bîrliba 1993 - S. Teodor, V. Mihăilescu-Bîrliba, Descoperiri monetare din aşezarea getică de la Poiana - Tecuci, AM 16, 121-130.

Teodor, Chriac 1994 — S. Teodor, C. Chiriac, Vase de sticlă din aşezarea getică de la Poiana (jud. Galați), AM 18, 183-222.

Teodor, Nicu, Țau 1994 - S. Teodor, M. Nicu, S. Țau, Tezaurul de monede callatiene descoperit la Poiana, jud. Galați, TD 8/1-2, 133-138.

Teodor, Nicu, Țau 1994 - S. Teodor, M. Nicu, S. Țau, Noi morminte din epoca bronzului descoperite la Poiana - Tecuci, MA 19, 201-212.

Teodor, Țau 1995 - S. Teodor, S. Ţau, Obiecte de port şi podoaba din aşezarea geto-dacică de la Poiana, jud. Galați, I Fibule, AM 19, 57-105.

Teodor, Nicu, Țau 1997 - S. Teodor, I. Nicu, S. Țau, Aşezarea geto-dacică de la Poiana, jud. Galați. Obiecte de port şi podoabă (II). Oglinzi, ace, obiecte de os, AM 20, 43-130.

Teodor, Nicu, Țau 1998 - S. Teodor, I. Nicu, S. Țau, Aşezarea geto-dacică de la Poiana, jud. Galați. Unelte, arme, piese de harnaşament şi alte obiecte din fier, bronz, lut ars şi piatră, AM 21, 43-133.

Turcu 1979 - M. Turcu, Geto-dacii din Câmpia Munteniei, Bucureşti.

Ursachi 1986, 1987 - V. Ursachi, Fortificații dacice pe Valea Siretului, Carpica 17-19, 31-51.

Ursachi 1968 - V. Ursachi, Cercetări arheologice efectuate la Muzeul de istorie din Roman, Carpica 1, 111-188.

Ursachi, Hordilă, Alexianu, Dumitroaia, Monah 1992 - V. Ursachi, D. Hordilă, M. Alexianu, Gh. Dumitroaia, Dan Monah, Cercetări de suprafață pe Valea Siretului, la nord de municipiul Roman, MA $18,145-176$.

Ursachi 1980 - V. Ursachi - Noi sisteme de fortificații în aşezarea dacică de la Brad (jud. Bacău), MCA Tulcea, 178-182.

Ursachi 1989 - V. Ursachi - Importurile greco-romane în cetatea dacică de la Brad, Symposia Thracologica 7, Tulcea, 281-283.

Ursachi 1995 - V. Ursachi, Zargidava. Cetatea dacică de la Brad, Bucureşti.

Ursachi 2003 - V. Ursachi, Fortificații dacice pe Valea Siretului (Fortifications daces de la Vallée de Siret), BMMN 1, 2, 46-53.

Vendelin 1939 - I. Vendelin, Săpăturile de la Barboşi, CNA 14/113-114, 141.

Vulpe şi colab. 1952 - Vulpe şi colab, Şantierul Poiana, SCIV 3, 191-230.

Vulpe 1957 - R. Vulpe, La civilizations dace et ses probléme a la lumiére des derniéres fouilles de Poiana, en Base Moldavie, Dacia N.S. 1, 143-165.

Vulpe 1966 - R. Vulpe, Aşezări getice din Muntenia, Bucureşti. 
Vulpe-Dunăreanu 1934 - E. Vulpe-Dunăreanu, Un tezaur de denari romani găsit la Piroboridava, În memoria lui Vasile Pârvan, Bucureşti.

Vulpe, Vulpe 1933 - R. Vuple, E. Vulpe, Fouilles de Poiana, Dacia 3-4, 277-351.

Vulpe, Teodor 2003 - R. Vulpe, S. Teodor, Piroboridava. Aşezarea geto-dacică de la Poiana, Bucureşti.

\section{LIST OF ILLUSTRATION}

Pl. 1. Geto-Dacian settlements and the positioning of the main dava-type settlements on the Siret Valey.

Pl. 2. The distribution of the Roman type brooches.

Pl. 3. The distribution of Delian cups - Greek imports and local imitations.

PI. 4. Getic coins and Roman hoards distribution.

Pl. 5. Brooches of La Tène $C$ type (1c,3), Brooches of La Tène $D$ type (6a, b, 7a1, 8a,b, 9a,b, 10a,b,c, $8,15 b, 16 a, b, d)$.

- Type 1a, Brooches with knots (the end of the $2^{\text {nd }}$ - during the $1^{\text {st }}$ BC.) Poiana.

- Type 3, Brooches of La Tène C type $\left(2^{\text {nd }}\right.$ - the end of the $1^{\text {st }}$ BC.) Poiana.

- Type $6 a, 6 b$, Brooches with frame-shaped catchplate $\left(1^{\text {st }}\right.$ BC. $)$ Poiana, Brad.

- Type 7a1, Filiform brooches of La Tène D type (72-25 BC.) Poiana.

- Type 8a, 8b, Filiform brooches of La Tène D type with inner chord (second half of the $1^{\text {st }} \mathrm{BC}$ until mid $\left.1^{\text {st }} \mathrm{AD}\right)$ Poiana, Răcătău.

- Type 9a, 9b, Filiform brooches with short bilateral spring and inner chord ("soldierly" brooches) (9a, second half/end of $1^{\text {st }} \mathrm{BC}-1^{\text {st }} \mathrm{AD}$; 9b second half of the $1^{\text {st }} \mathrm{AD}$ ) Poiana, Brad, Răcătău.

- Type 10a, 10b, 10c, Brooches with large bilateral spring and chord wound onto the bow (10a, 10b, end of the $1^{\text {st }} \mathrm{BC}$ - until mid or third quarter of the $1^{\text {st }} \mathrm{AD}$.; $10 \mathrm{c}$ third quarter of the $1^{\text {st }} \mathrm{AD}-2^{\text {nd }} \mathrm{AD}$ ) Poiana, Brad.

- Type 11, Rhomboidal shield-shaped brooches (second half of the $1^{\text {st }} \mathrm{BC}$ ) Poiana.

- Type 13, Nauheim brooches (70/60 BC şi 30/20 BC) Răcătău.

- Type 15b, "angular" bow brooches $\left(1^{\text {st }}\right.$ BC. $-1^{\text {st }}$ AD) Brad.

- Type 16a, 16b, 16d, "Spoon" type brooches (16a, 16b, end of the $1^{\text {st }} \mathrm{BC}$ - half/third quarter of the $1^{\text {st }} \mathrm{AD} ; 16 \mathrm{~d}$ last quarter/end of the $1^{\text {st }} \mathrm{BC}$ until mid/third quarter of the $1^{\text {st }} \mathrm{AD}$ ) Barboşi, Poiana, Brad, Răcătău.

Pl. 6. Roman type brooches with bilateral spring (19a, b, c, 20a, b, c, f, 21, 22, 23, 24, 26), Hinged Roman type brooches (29, 30a), Disk-shaped flat brooches (31g).

- Type 19a, 19b, 19c, Strongly profiled brooches $\left(19 \mathrm{a}, 1^{\text {st }} \mathrm{BC}-\right.$ beginning of the $1^{\text {st }} \mathrm{AD} ; 19 \mathrm{~b}$, first three quarters of the $1^{\text {st }} \mathrm{AD}, 19 \mathrm{c}, 1^{\text {st }} \mathrm{AD}$.) Brad, Poiana, Răcătău.

- Type 20a, 20b, 20c, 20f, Eastern strongly profiled brooches (20a, 20b, end of the $1^{\text {st }} \mathrm{C}$ - beginning of the $2^{\text {nd }} \mathrm{AD} ; 20 \mathrm{c}$ second half of the $\left.1^{\text {st }} \mathrm{AD} ; 20 \mathrm{f} 2^{\text {nd }} \mathrm{AD}\right)$ Barboşi, Brad, Poiana, Răcătău.

- Type 21, Brooches with zoomorphic ornaments on the bow (27 BC - 14 AD/41-54 BC) Poiana, Răcătău.

- Type 22, "Broken" -bow brooches (end of the $1^{\text {st }} \mathrm{BC}-1^{\text {st }} \mathrm{AD}$ ) Brad, Răcătău.

- Type 23, "Eyed" brooches (first or the second decade of the $1^{\text {st }} \mathrm{AD}$ until the third quarter of the same century) Brad, Poiana, Răcătău.

- Type 24, Norico-Pannonian type brooches (end of the $1^{\text {st }} \mathrm{BC}$ until mid. $1^{\text {st }}$ AD) Barboşi, Brad, Răcătău.

- Type 26, Langton-Down type brooches (end of the $1^{\text {st }} \mathrm{BC}$ - beginning of the second half of the $1^{\text {st }}$ AD) Poiana.

- Type 29, Brooches of Aucissa type (end of the $1^{\text {st }} \mathrm{BC}$ until first half of the $1^{\text {st }} \mathrm{AD}$ ) Barboşi (?) Poiana, Răcătău.

- Type 30, "Little-wings brooches" (second and third quarter of the $1^{\text {st }} \mathrm{AD}$ ) Poiana, Răcătău.

- Type 31, Disk-shaped flat brooches (31a, 20-50 AD; 31b, second quarter of the $1^{\text {st }}$ AD; 31f a second half $1^{\text {st }}$ AD.) Brad, Poiana. 


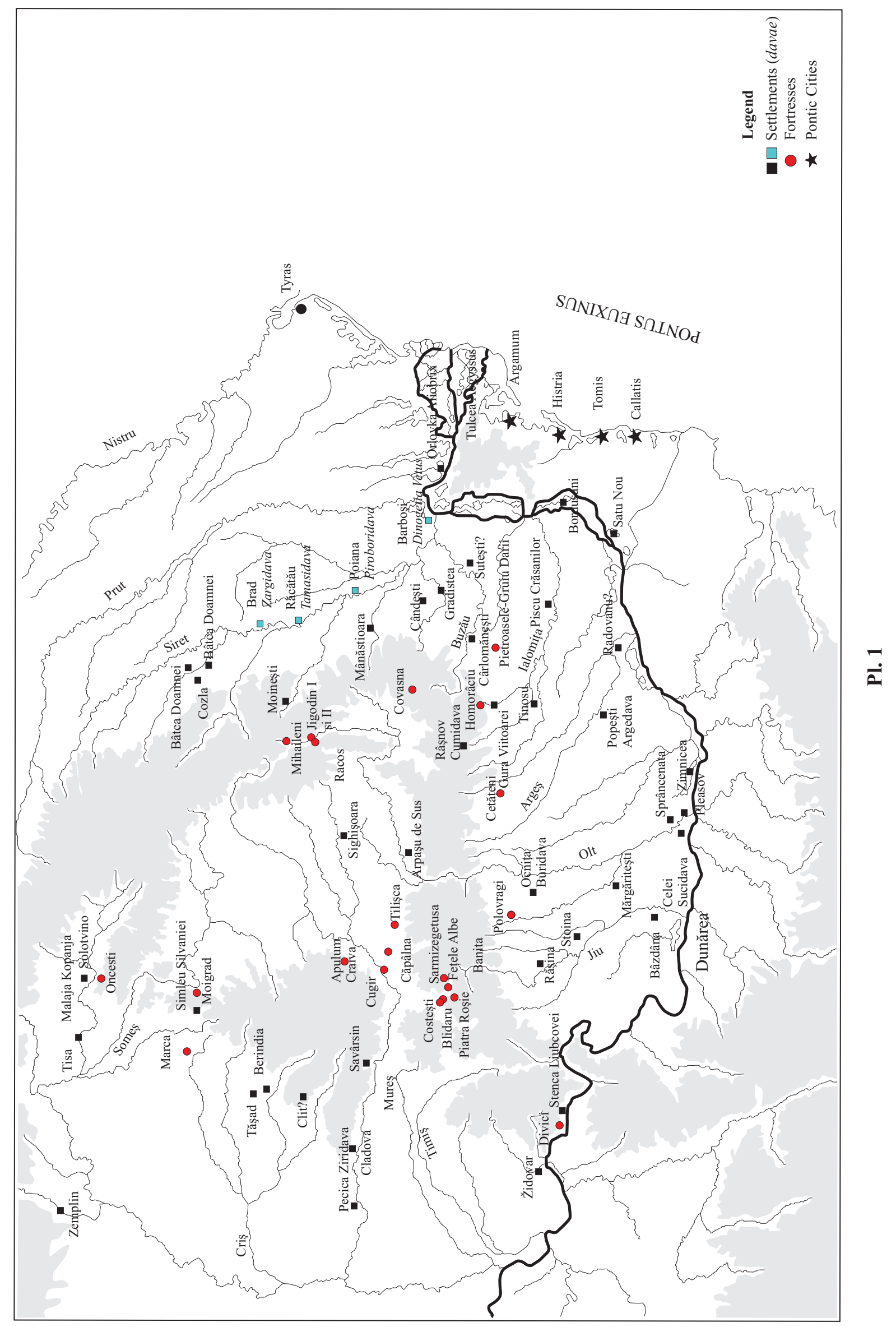




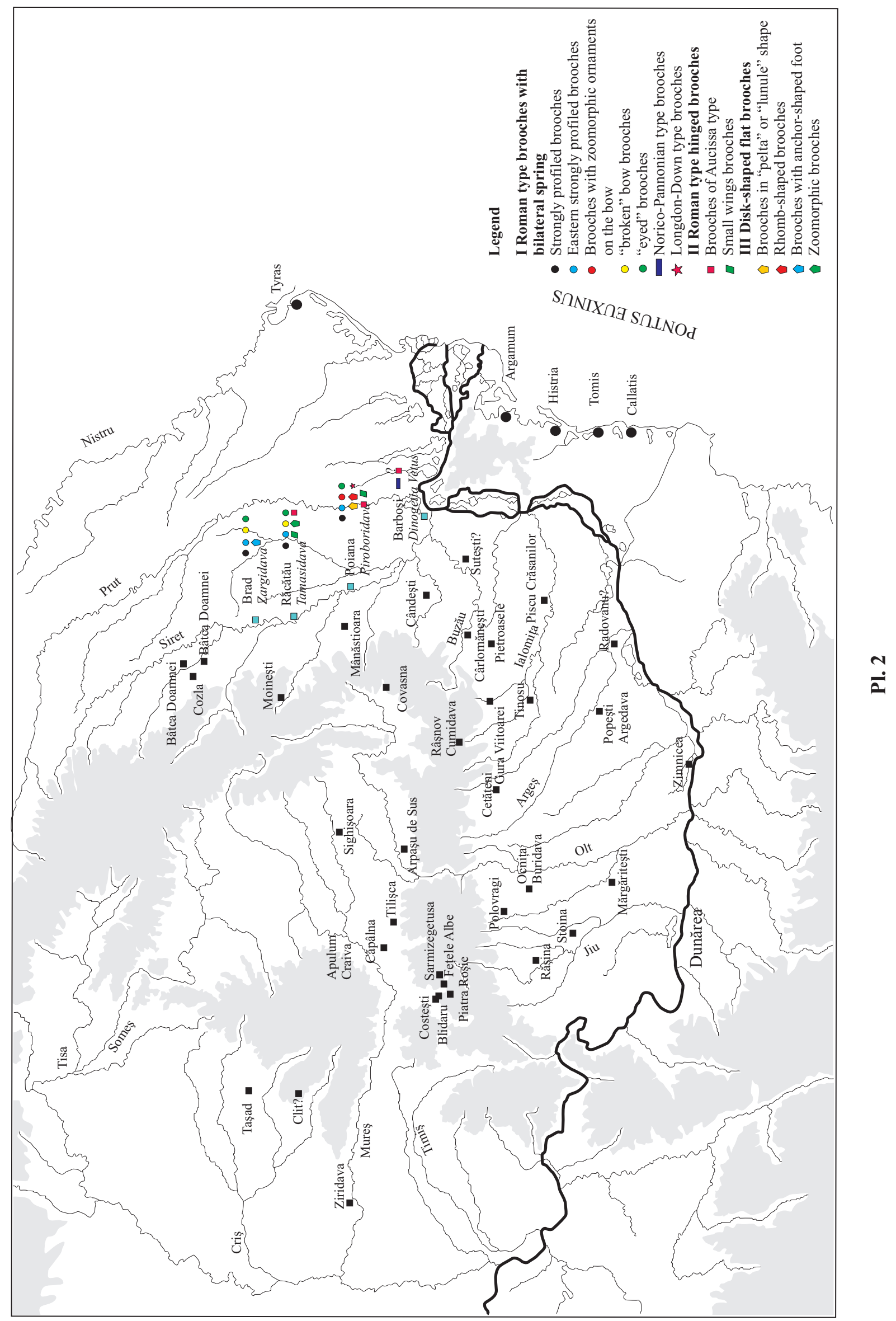




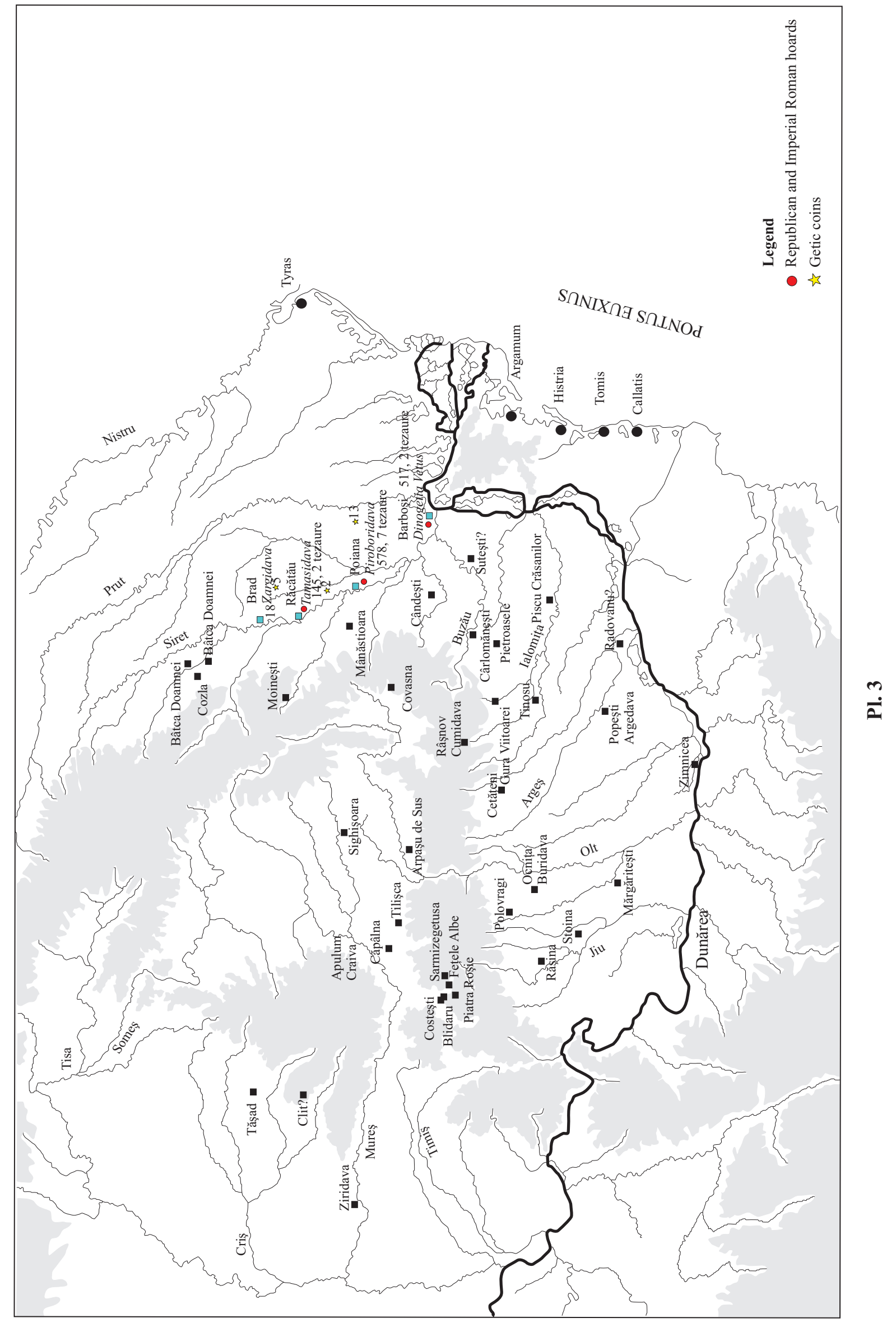




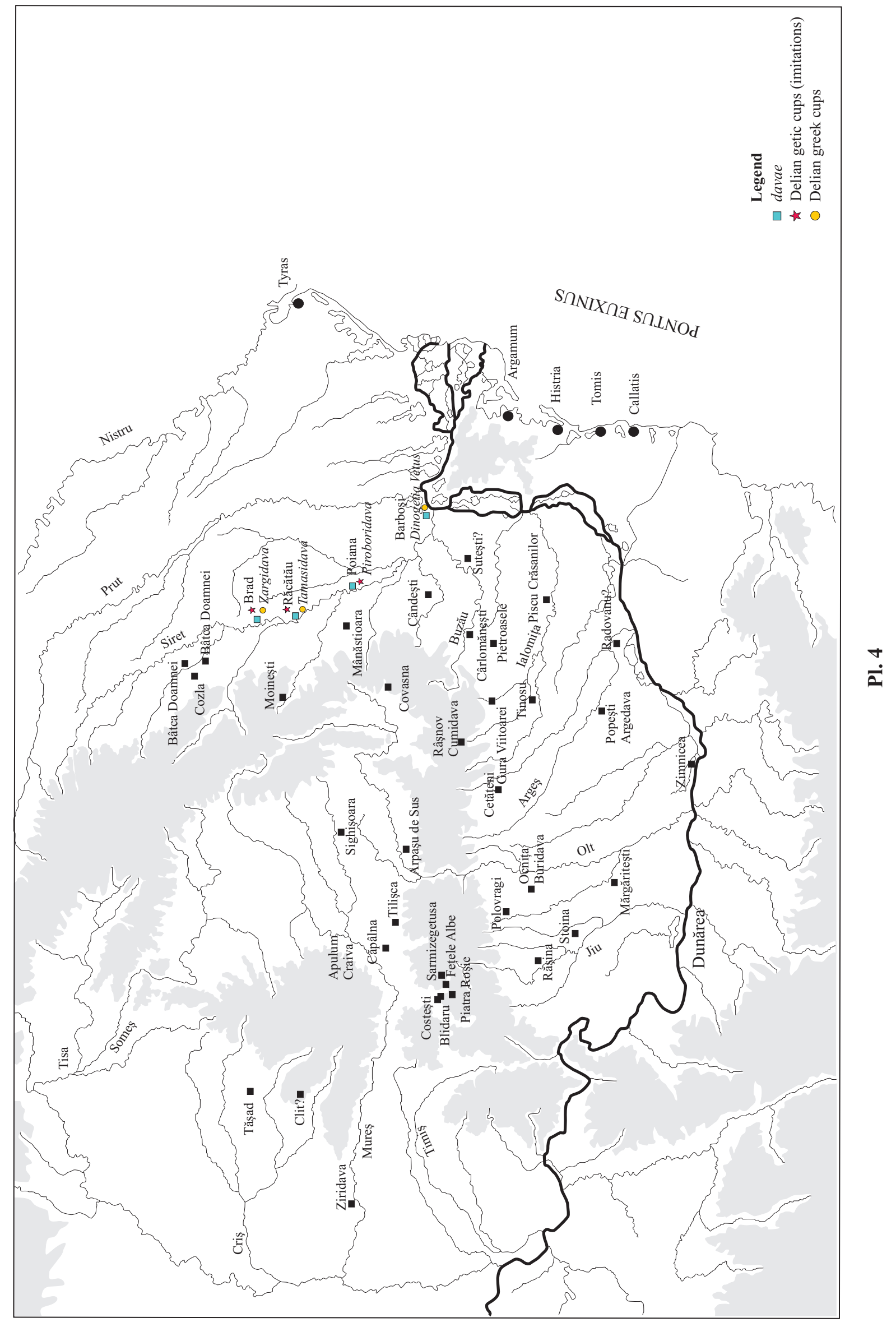




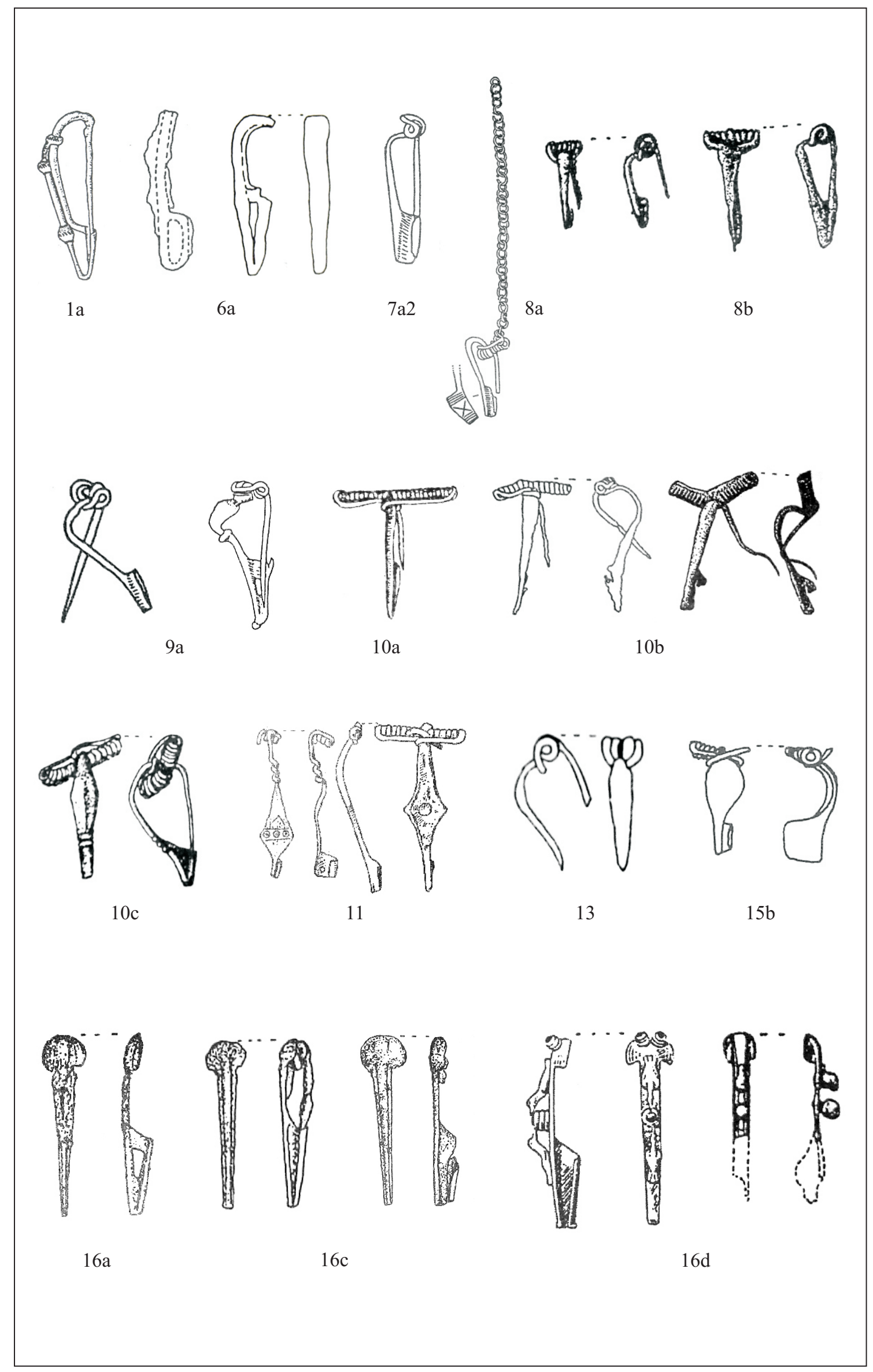

Pl. 5 


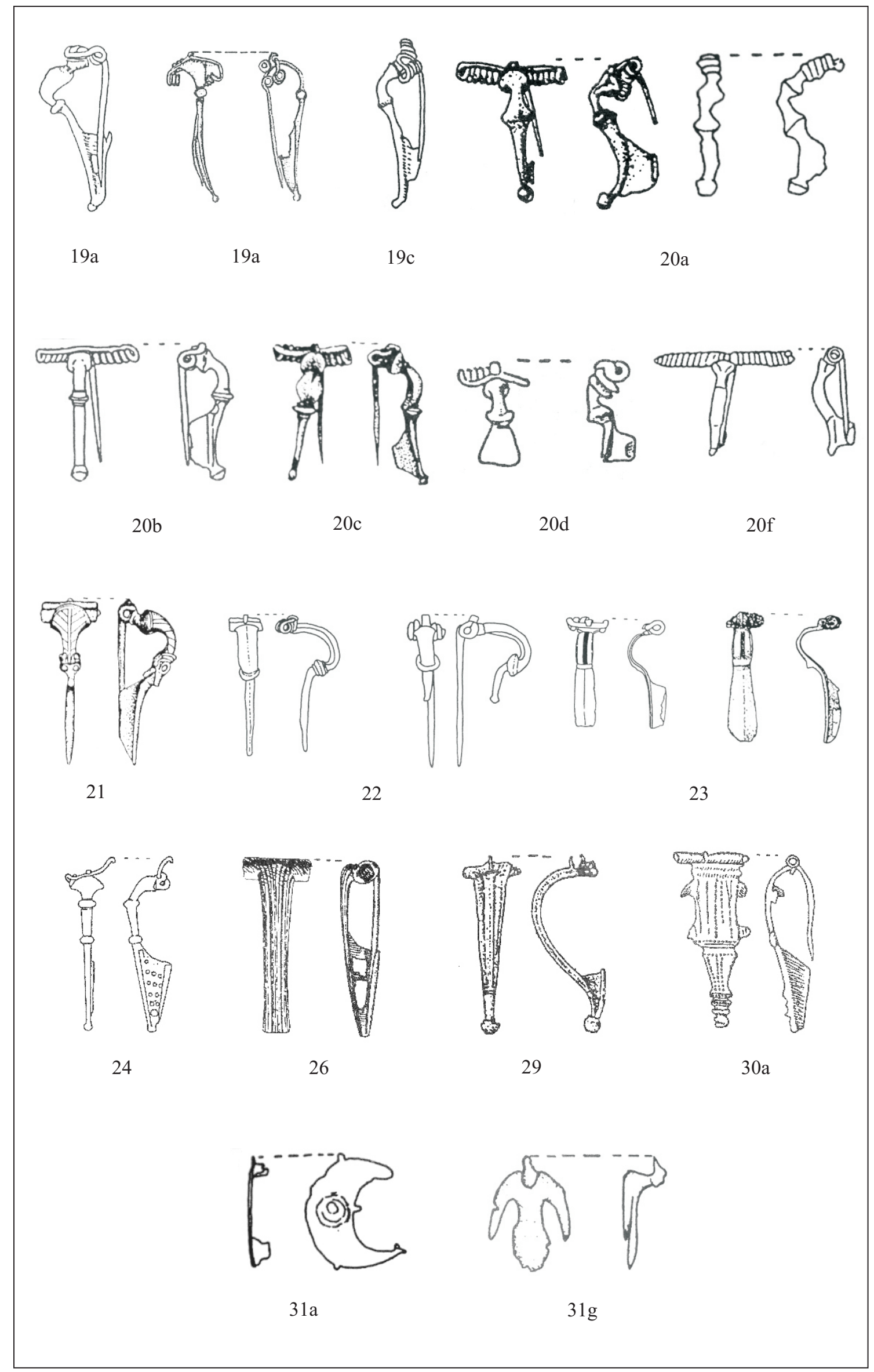

Pl. 6 